\title{
Lingulate brachiopods from the Suchomasty Limestone (upper Emsian) of the Barrandian, Czech Republic
}

\author{
MICHAL MERGL \& ANDREA JIMÉNEZ-SÁNCHEZ
}

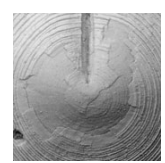

\begin{abstract}
Lingulate brachiopod fauna from Suchomasty Limestone (upper Emsian, P. serotinus Zone) are examined. Eleven species were observed, of which Kosagittella robusta, Chynithele intermedia, Lochkothele rugellata and Praeohlertella lukesi are described as new taxa. Associated Opatrilkiella kobyla, Havlicekion frydai and Opsiconidion coralinus were described previously from the Chýnice Limestone of the Barrandian area. Four taxa are left in open nomenclature including further evidence of the siphonotretid Orbaspina in the upper Emsian. The composition of the fauna shows distinct difference to other Emsian and Eifelian lingulate brachiopod faunas of the Koněprusy area of the Barrandian. $\bullet$ Key words: Lingulata, Discinoidea, Siphonotretida, Emsian, Suchomasty Limestone, taxonomy, Koněprusy, Barrandian.
\end{abstract} MERGL, M. \& JIMÉNEZ-SÁNCHEZ, A. 2015. Lingulate brachiopods from the Suchomasty Limestone (upper Emsian) of the
Barrandian, Czech Republic. Bulletin of Geosciences 90(1), 173-193 (11 figures). Manuscript received September 2,
2014; accepted in revised form November 18, 2014; published online January 8, 2015; issued January 26, 2015.

Michal Mergl \& Andrea Jiménez-Sánchez, Centre of Biology, Geosciences and Environmental Sciences, Faculty of Education, University of West Bohemia in Plzeň, Klatovská 51, Plzeň, 30619, Czech Republic; mmergl@cbg.zcu.cz, jimenez@cbg.zcu.cz

The Koněprusy area in SW part of the Silurian-Devonian sequence of the Barrandian area is a famous and unique source of diverse and well-preserved Pragian, Emsian and Eifelian fossils for more than one-and-half centuries. The present concept of stratigraphy of Koněprusy reef complex is based on a series of early studies of Chlupáč $(1955,1956$, 1957, 1959) supplemented by contributions devoted to various aspects of the reef by the same author (Chlupáč 1983, 1996, 2003). Geology, commonest fossils and benthic associations of the Koněprusy (Pragian), Suchomasty (upper Emsian) and Acanthopyge (Eifelian) limestones were described in tens of modern monographs, short reports, field guides and popular articles (for references see Chlupáč 1984, 1996, 2003). All works indicate the uniqueness of the Koněprusy reef complex in the Lower and Middle Devonian (Chlupáč 1984, 1994, 1998).

In 1846, Joachim Barrande was the first who contributed to the taxonomy of fossils of the Suchomasty Limestone. This work was followed by his series of monographs on the brachiopods (Barrande 1847, 1848, 1879), in which many of species of this unit were described. Modern extensive taxonomic studies of the fauna of the Suchomasty Limestone were published after the Second World War by Prantl \& Přibyl (1949, 1954), Havlíček (1959, 1961, 1971, 1985, 1987), Šnajdr (1960, 1980), Chlupáč \& Vaněk (1957) and Chlupáč (1977). Tens of short reports and taxonomic studies concerning the fauna of the Suchomasty Limestone by these and other authors do exist, some of them cited in these monographs. In addition to the very diverse invertebrate groups, including stratigraphically important goniatites (Chlupáč \& Turek 1983) and tentaculitoids (Ferrová et al. 2012), remains of a placoderm were observed in the Suchomasty Limestone (Vaškaninová \& Kraft 2014).

Rhynchonelliformean brachiopods of the Suchomasty and Acanthopyge limestones were monographed by Havlíček \& Kukal (1990). In contrast to the diverse and generally smooth-shelled rhynchonelliformean brachiopods, the organophosphatic brachiopods are much less attractive and they were always outside the interest of collectors and researchers. A few species coming from the Suchomasty Limestone were briefly mentioned by Mergl (2001). The gap in organophosphatic brachiopod data is caused by the extreme rarity and diminutive size of these brachiopods. The present better knowledge of organophosphatic brachiopods from units below (Koněprusy and Chýnice limestones; Mergl 2001, Mergl \& Ferrová 2009) and above (Acanthopyge Limestone; Mergl 2009) was the main reasons for intensive sampling for these brachiopods in the Suchomasty Limestone.

\section{Geological setting}

The Suchomasty Limestone (upper Emsian) is the name for the local lithostratigraphic unit in the Koněprusy area, in a small area SW from Prague, the capital of the Czech 
Republic (Fig. 1). It disconformably covers the reefal Koněprusy Limestone of the Pragian age (Chlupáč 1998) after late Pragian-early Emsian (Zlichovian) emersion and erosion. The beginning of the deposition of the Suchomasty Limestone is dated in only two sections (Červený lom Chlupáč et al. 1979; Voskop Quarry - Frýda 1992) to the Nowakia elegans Biozone, but above the $N$. barrandei-elegans Subzone (see Ferrová et al. 2012). The Suchomasty Limestone sequence is dominated by well bedded reddish and grey biomicritic and biosparitic, predominantly crinoidal limestones, with thickness reaching up to $30 \mathrm{~m}$. Sorting of bioclasts, lense-like accumulations of fossils and gradded bedding indicate a shallow-water and higher energy environment (Havlíček \& Kukal 1990, Chlupáč 1998). The tentaculite fauna includes the Nowakia elegans, N. cancellata, N. richteri and $N$. holynensis zones (Chlupáč et al. 1979, 1986; Berkyová 2004; Ferrová et al. 2012). Upper Emsian age is evidenced by the Polygnathus laticostatus, P. serotinus and P. costatus partitus zones (Klapper 1977, Klapper et al. 1978, Chlupáč et al. 1986, Chlupáč 1998, Berkyová 2009).

The Suchomasty Limestone also fills many vertical or oblique neptunian dykes, which penetrate the Pragian reefal Koněprusy Limestone and the Kotýs Limestone of the Lochkovian age below. The Suchomasty Limestone filling of the dykes shows variable lithology and polyphase origin of most dykes. The dykes follow an E-W strike. Thickness of the dykes range from a few $\mathrm{cm}$ to $20 \mathrm{~m}$, their depth may be over 100 below their funnel-shaped mouth. Neptunian dykes, described and subsequently reviewed by Chlupáč $(1955,1996)$ are an important source of abundant fossils, namely trilobites and brachiopods.

\section{Material and methods}

Very few lingulate brachiopods have been found by hammering due their rarity and small size. Their occurrences are accidental. The majority of material was yielded by etching of limestone. Around $100 \mathrm{~kg}$ of limestone have been etched by $10 \%$ solution of acetic acid. Residues were washed by stagnant water and unsieved to prevent secondary fragmentation. In total, 250 determinable brachiopod specimens were picked, together with abundant conodonts and conulariid fragments, and less abundant spines of phyllocarid crustaceans, dermal plates of placoderms, and Eurytholia sclerites.

Most of the phosphatic fossils were sampled at localities 3 and 5. Phosphatic lingulate brachiopod shells are white or pale grey in colour. Shells are extremely fragile, and more robust parts (thickened peripheries and apices) prevail in all residues. Small fragments prevail over more complete parts of shells in the residues, but this feature is likely the result of fragmentation during etching of the rock. No worn shells were observed. In contrast to etched material, the few shells collected by hammering are mostly complete.

Material was studied by SEM JSM-6300 with shells on stabs covered by gold. Some ammonium chloride coated specimens were photographed under a binocular lens OLYMPUS SZX 7 with use of the Deep Focus 3.1 software. Larger specimens were coated by ammonium chloride and photographed by an OLYMPUS E-410 Camera using a macroobjective ZUYKO Digital $35 \mathrm{~mm}$.

The four most complete discinid specimens obtained by hammering were subsequently covered by a thick mat of artificial acrylate resin DENTACRYL and the rock below the fossils was etched by a $10 \%$ solution of acetic acid. The original unbroken phosphatic shell in its resin base remained preserved showing its exterior (specimens figured on Figs 6A, B, E, F, 7B, 8B, C, E, I, L).

\section{Localities}

Locality 1. - NW part of the Císařský lom Quarry, a neptunian dyke in NW wall of the quarry (locality 3 of Havlíček \& Kukal 1990; site 20a and 21b of Chlupáč 1996) filled by reddish crinoidal limestone. Conodonts Icriodus sp., Belodella sp.

Locality 2. - E wall of the Císařský lom Quarry near the top of the Zlatý kůn̆ hill. A source rock is bedded red crinoidal limestones in the upper part of the Suchomasty Limestone, 4-5 $\mathrm{m}$ below the Acanthopyge Limestone. Sampling site is slightly southwards to locality 2 of Havlíček \& Kukal (1990). Conodonts Belodella sp., Ozarkodina carinthica (Schulze, 1968), Polygnathus bultyncki Weddige, 1977, Polygnathus serotinus Telford, 1975 indicate the $P$. serotinus Zone.

Locality 3. - Petrbok Quarry, rock debris on the floor of quarry. A source rock is reddish biomicritic crinoidal limestone of the lower part of the Suchomasty Limestone, near site 30 of Chlupáč (1996), with rare and small brachiopod fauna with Dalejodiscus. Conodonts Icriodus sp., Belodella sp., Pseudooneotodus sp.

Locality 4. - Herget's Quarry, NE wall. A source rock is light grey crinoidal limestone of the Suchomasty Limestone (locality 5 of Havlíček \& Kukal 1990 and near site 30 of Chlupáč 1996), with the typical Karbous-Orbitoproetus Community. Conodonts Belodella sp., Polygnathus serotinus Telford, 1975.

Locality 5. - N slope of the "Na Voskopě" hill, outcrops of subhorizontal reddish and grey, biosparitic, often crinoidal limestones in the upper part of the Suchomasty Limestone (locality of Havlíček \& Kukal 1990). No conodont data.

Locality 6. - E part of the "Na Voskopě" hill, a neptunian dyke filled by rose and reddish biosparitic limestones in 


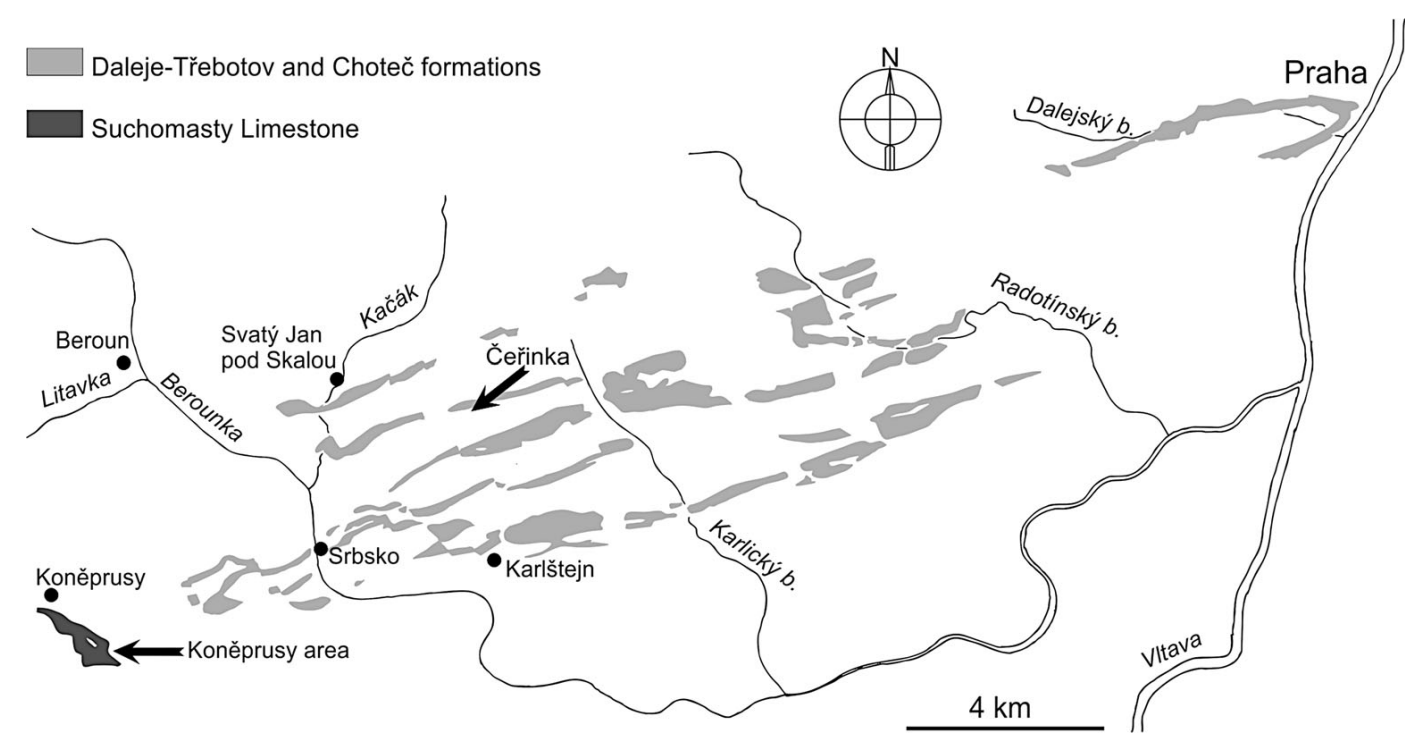

Figure 1. Schematic map showing location of the Prague Basin in the Barrandian area in the Czech Republic and distribution of the Daleje-Třebotov and Choteč formations, with location of the Koněprusy area and the Suchomasty Limestone. Locality of the Chýnice Limestone near Bubovice is marked by arrow. Modified after Ferrová et al. (2012).

E wall of the quarry (locality 13 of Havlíček \& Kukal 1990). Sample comes from the "Main Dyke", sites 25 and 26 described and illustrated by Chlupáč (1996, figs 1, 11, 12), with the Orbitoproetus-Scabriscutellum Community. Conodonts Belodella sp., Icriodus beckmani sinuatus Klapper, Ziegler \& Mashkova, 1978, Icriodus beckmanni cf. beckmanni Ziegler, 1956, Polygnathus bultyncki Weddige, 1977 and Polygnathus linguiformis cf. pinguis Weddige, 1977 indicate the lower part of the $P$. serotinus Zone.

Locality 7. - W part of the "Na Voskopě" hill, a neptunian dyke in $\mathrm{W}$ wall of the quarry (near locality 13 of Havlíček \& Kukal 1990) filled by reddish crinoidal limestone. Westward prolongation of the "Main Dyke", near the site 28 of Chlupác (1996, fig. 1), with abundant Phacops maior Barrande, 1852. Conodonts Belodella sp., Polygnathus sp.

\section{Systematic part}

Repository. - All specimens, including the types, are housed in the palaeontological collections of the Centre of Biology, Earth and Environmental Sciences in the Faculty of Education of the University of West Bohemia in Plzen (PCZCU).

Abbreviations. - $\mathrm{H}$ - height, $\mathrm{L}$ - length, $\mathrm{W}$ - width.

Order Lingulida Waagen, 1885

Order Lingulida Menke, 1828

Family Obolidae King, 1846

Subfamily Obolinae King, 1846

\section{Genus Kosagittella Mergl, 2001}

Type species. - Kosagittella clara Mergl, 2001; Kopanina Formation, Ludlow, Silurian; Prague Basin, Czech Republic.

Remarks. - The stratigraphic range of the genus Kosagittella occupies the Ludlow to the Eifelian. At present, the genus is known only from the Barrandian area (Mergl 2001, 2009; Mergl \& Ferrová 2009; Mergl \& Vodrážková 2012). There is a succession of several species, with the earliest $K$. clara Mergl, 2001 (Ludlow), followed by K. pinguis Mergl, 2001 (Lochkovian), K. lingua (Barrande, 1879) (Pragian), K. robusta sp. nov. (Emsian), and K. pulsatilla Mergl, 2009 (Eifelian). Specimens sampled in the Chýnice Limestone (upper Emsian) were left in open nomenclature (Mergl \& Ferrová 2009). Other poorly preserved specimens sampled in the Třebotov Limestone (upper Emsian, $P$. serotinus Zone) were referred to $P$. pulsatilla (Mergl \& Vodrážková 2012). Generic identification of the shell fragments is rather easy due to the characteristically pitted exterior of shell and the surface of dorsal propareas (Mergl \& Ferrová 2009, fig. 2K-M). However, the identification to the species level more difficult, because shells extracted from the rock by etching are generally incomplete and exfoliated and shells resting in rock show only the general size and outline, often without critical diagnostic features. Internal morphology of the genus is poorly known, mainly due to its small and thinner shell, and fragmentary state of preservation of the specimens yielded by dissolution of limestone. Unlike other species, the new material from the Suchomasty Limestone is favourably preserved and more numerous. 


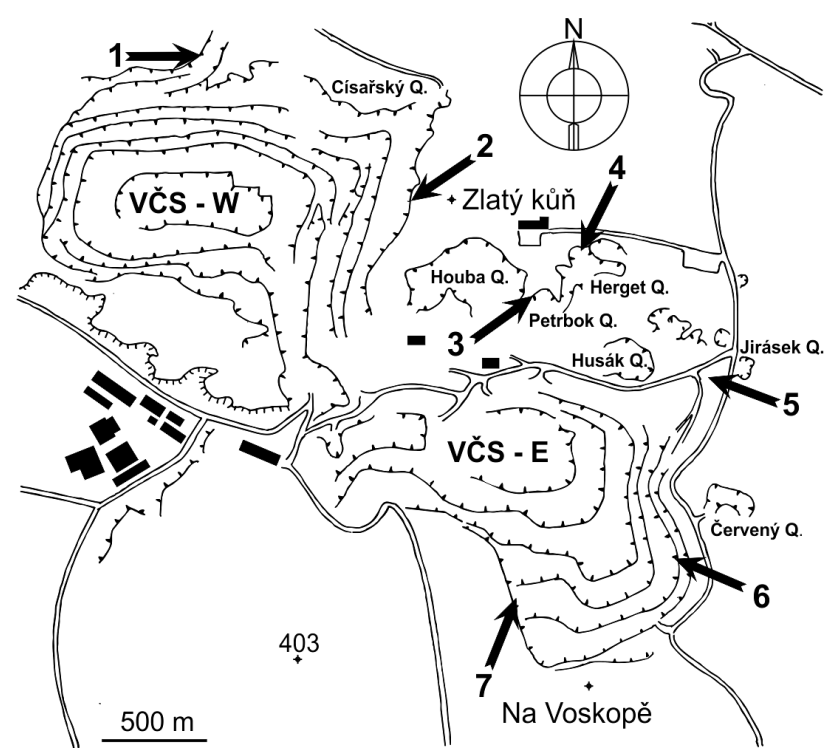

Figure 2. Schematic map showing quarries in the Koněprusy area and location of sampled localities of the Suchomasty Limestone. Modified after Chlupáč (1996).

There are distinct morphological changes in the evolutionary history of the genus. The earliest $K$. clara already displays a thickened posterior part of the ventral valve, with an apsacline ventral interarea having posterolaterally sloping undivided propareas. The pedicle groove is short and internally continues as a distinct groove sloping on the subvertical posterior shell floor of the visceral area. Posterior shell wall is thickened, ventral propareas are not excavated and shell progressively thins anteriorly.

The attitude of the pedicle groove and estimated shape of the pedicle needs commentary. The pedicle, after protrusion between the valves, was more or less curved ventrally. We have not any direct data about the pedicle length and size, but this ventral turning indicates, that Kosagittella was not a usual lingulate. Lingulates with a burrowing habitat have the apex directed downwards and a posteriorly directed pedicle groove (Emig 1983, 1997). It is well demonstrated by the shape of the pedicle groove in recent Lingula anatina (Emig 1982) as well as in very ancient lingulates (Zhang et al. 2004, 2007). An ovoid shell outline and higher convexity of Kosagittella is concordant with an epibenthic habitat, but not for a vertical attitude of the shell. The living animal rested on the sea floor or was attached to large bioclasts with the ventral valve facing a substrate. There are few reports of intimate association of small lingulates with corals (Newall 1970) or stromatoporoids (Tapanila \& Holmer 2006). No significant deviation in the abundance of Kosagittella in the Suchomasty Limestone in which corals and stromatoporoids are rare and the Acanthopyge Limestone in which abundant corals were observed. It is good negative evidence against the similar symbiotic coral or stromatoporoid relationships of Kosagittella.

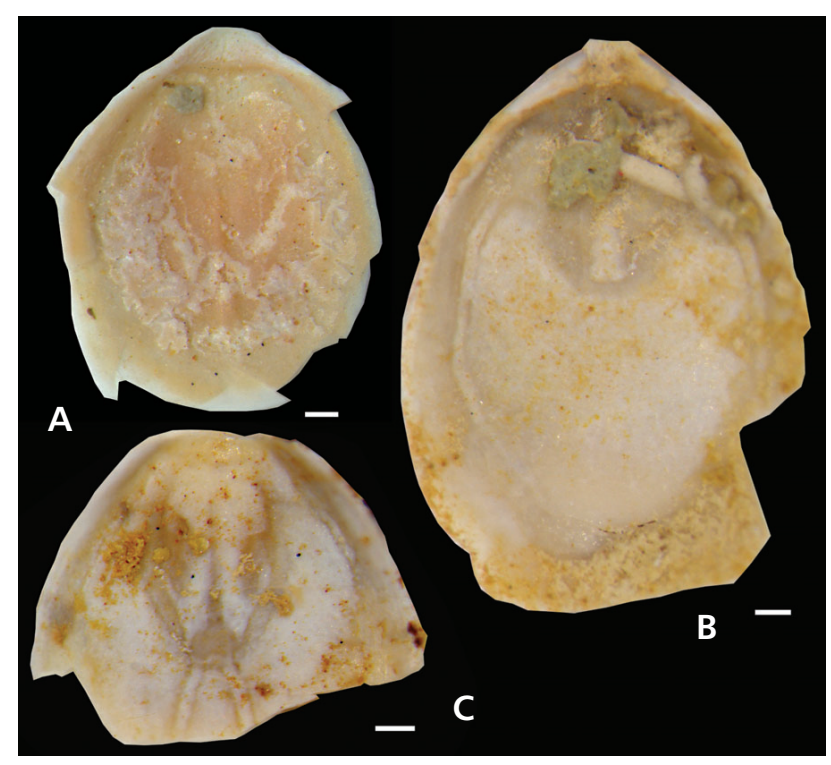

Figure 3. Kosagittella robusta sp. nov., Suchomasty Limestone, Koněprusy, locality 6. • A - incomplete dorsal valve, interior, PCZCU 1916. - B - incomplete dorsal valve, interior, PCZCU 1917. • C - ventral valve, interior, PCZCU 1918. Bar $=200 \mu \mathrm{m}$.

\section{Kosagittella robusta sp. nov.}

Figures 3, 4

2009 Kosagittella sp. - Mergl \& Ferrová, p. 526, fig. 2.

2012 Kosagitella pulsatilla Mergl, 2009 (partim). - Mergl \& Vodrážková, p. 318, fig. 2.

Holotype. - Dorsal valve figured on fig. 2C, D, F, J, M (PCZCU 1910).

Type horizon. - Upper Emsian, Suchomasty Limestone, lower part of the Polygnathus serotinus Zone.

Type locality. - Koněprusy, "Na Voskopě" hill, neptunian dyke in $\mathrm{E}$ wall of the quarry (locality 6).

Material. - Fifty shells, most of them fragmental.

Diagnosis. - Moderately thick-walled Kosagittella with slightly convex transverse profile and a subangular weakly pointed posterior margin of the ventral valve, distinct and moderately long ventral pseudointerarea, and distinct impressions of the visceral area, muscle scars and pallial markings on the shell interior.

Description. - Shell is elongate, oval, moderately thickwalled relative to its size, 3.8 to $4.0 \mathrm{~mm}$ long.

Length of the dorsal valve is around $150 \%$ of the maximum width. The maximum width of the dorsal valve is at about shell midlength. Posterior margin is evenly rounded, in apical part gently extended by a slightly overhanging 


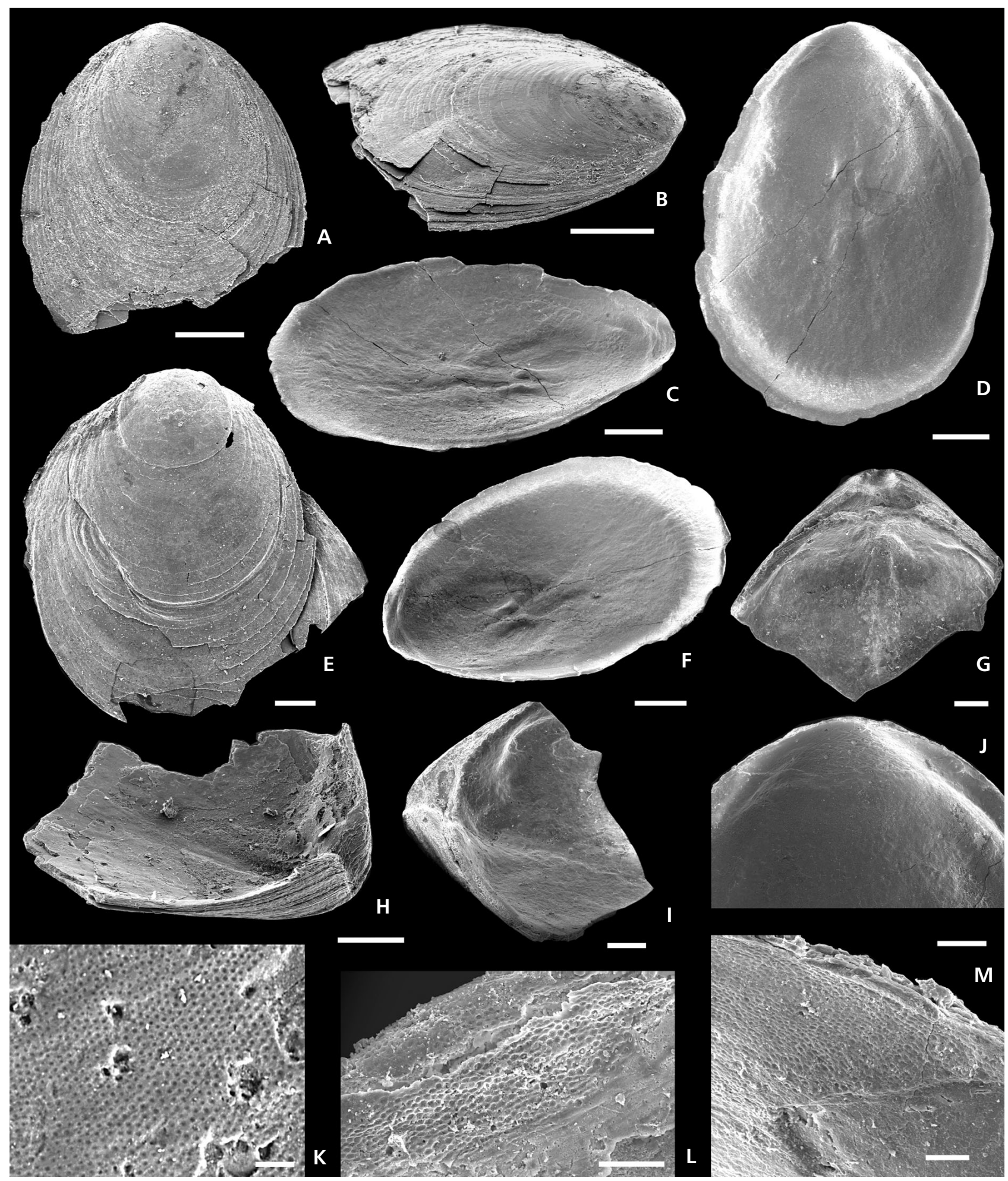

Figure 4. Kosagittella robusta sp. nov., Suchomasty Limestone, Koněprusy, locality 6. • A, B - dorsal valve, exterior, PCZCU 1909. • C, D, F, J, M dorsal valve interior in dorsal view, two oblique views showing visceral area, detail of interarea, and pitting on internal surface of interarea, PCZCU 1910. - E - ventral valve, exterior, PCZCU 1911. • G, I - ventral valve, interior, PCZCU 1912. • H - ventral valve, oblique view to interarea, PCZCU 1915. $\cdot \mathrm{L}$ - external microornament of pits, PCZCU 1914. $\bullet \mathrm{K}$ - pitted posterolateral margin of dorsal pseudointerarea, PCZCU 1913. Bar $=500 \mu \mathrm{m}(\mathrm{A}-\mathrm{D}, \mathrm{F})$, $200 \mu \mathrm{m}(\mathrm{E}, \mathrm{G}-\mathrm{J})$, and $20 \mu \mathrm{m}(\mathrm{K}-\mathrm{M})$. 
edge of the brephic shell. The valve is moderately convex axially as well as transversally.

Interior of the dorsal valve has a weakly defined, very low, deeply concave broadly triangular median groove laterally bordered by small undivided orthocline propareas. Very fine step delineates borders of median groove and closely adjacent propareas from the adjacent valve floor. Fila parallel to the shell margins cover the surface of the median groove, forming a sub-reticulate ornament by their intersections (Fig. 4J). The dorsal visceral area is subrhomboidal, $40-45 \%$ as long and $50-55 \%$ as wide as the valve, gently impressed into the valve floor. A low callus covers the axial part of visceral area in front of the median groove.

A weak slit along the shell axis between secondary deposits of the central muscle scars is apparent at one-third of the valve length. Muscle scars are weakly defined, with undivided, obliquely elongate scars on posterolateral slopes of visceral area (= transmedian, outside and middle lateral muscles). Large oblique and anteriorly converging central muscle scars, and similarly sized and shaped anterior lateral muscle scars are located posterocentrally on the valve floor. Sites and outlines of muscle scars are discernible in uncoated shells as dark spots (Fig. 3C).

Vascula media moderately diverge anteriorly. They are preserved as thin, proximally undivided canals which branch into more but weakly defined secondary canals in the anterior third of the valve. Vascula lateralia are weakly defined as a pair of narrow, arcuate and undivided canals paralleling valve margins to almost two-third of valve length.

The ventral valve is more elongate, with an acutely subangular posterior margin. Apical angle subtends an angle of $90^{\circ}$. The posterior shell wall is remarkably much thicker than the walls in other parts of the valve and the apical part of the dorsal valve.

The pedicle groove is short, broad, moderately deep and posteriorly tapering. Ventral interarea is apsacline, short, with striated and outwardly sloping propareas. Propareas and floor of the pedicle groove are built by thick lamellose deposits accreted to the posterior shell wall. Ventral interior shows a small broadly rhomboidal visceral area, about $25 \%$ long as the valve, with large central muscle scars and undivided muscle scars in the posterolateral periphery of the visceral field. A moderately deep groove that is an anterior prolongation of the pedicle groove on the almost vertical posterior slope of the visceral area is distinct in larger shells. This groove anteriorly ends in a shallow pit on the valve floor, from which weakly divergent imprints of pedicle nerves extend (Fig. 4H). Vascula lateralia consist of narrow, evenly wide canals paralleling the shell margins, projecting from the visceral area between the central and undivided posterior muscle scars. From the midlength of the valve the canals converge becoming subdivided into narrow and obscure secondary branches (Fig. 3B).

The brephic shell is subcircular, $600 \mu \mathrm{m}$ wide, gently convex in both profiles. The ventral larval shell has a low subcircular node, the dorsal valve is evenly smooth. Periphery of the brephic shell is distinct and raised above surface of the mature shell. The surface of the brephic shell bears concentric and evenly sized regular growth lines that become more distinct anterolaterally. The mature shell is covered by infrequently spaced, but prominent growth lines. Microornament of mature shell consists of distinct circular pits regularly covering the entire surface of a mature shell (Fig. 4K, L).

Remarks. - The new species is morphologically almost indistinguishable from Kosagittella pulsatilla Mergl, 2009 described from the Acanthopyge Limestone (Eifelian) of the Koněprusy area, but can be differentiated by two distinct features. Firstly, K. pulsatilla has a much extended and in transverse profile more convex posterior part of the ventral valve, which however, has a much smaller and shorter pseudointerarea. This is formed by a short shelf with a very short pedicle groove in $K$. pulsatilla. The pseudointerarea is longer and robust in $K$. robusta. The second difference is in the thickness of a shell wall. K. pulsatilla has a thinner shell wall, with correspondingly weaker impressions of muscle scars, pallial markings and the visceral area. Specimens figured by Mergl \& Vodrážková (2012) were referred to $K$. pulsatilla. The first of three figured specimens (Mergl \& Vodrážková 2012, fig. 7B-D) likely belongs to K. robusta. However, because this specimen is incomplete and its interior is not satisfactory known, it is hard to determine this specimen unambiguously. Its attribution to $K$. robusta is based on the less extended posterior of the valve and the stratigraphical level of the sample ( $P$. serotinus Zone). The morphology of shell might be influenced by substrate and environment, but difference between $K$. pulsatilla and $K$. robusta are distinct in many specimens of both species. Specimens referred to $K$. sp. from the Chýnice Limestone (upper Emsian) can be referred to $K$. robusta by its more rounded posterior margin of the ventral valve and the more transverse outline of the brephic shell (Mergl \& Ferrová 2009, fig. 2D, G) compared with more elongate brephic shell of $K$. pulsatilla (Mergl 2009, fig. 3E).

Occurrence. - Daleje-Třebotov Formation, Suchomasty Limestone, Koněprusy, lower part of $P$. serotinus Zone, locality 2 (rare), locality 3 (rare), locality 5 (rare), locality 6 (abundant); Třebotov Limestone, $P$. partitus Zone, Choteč, Na Škrábku Quarry (very rare). 


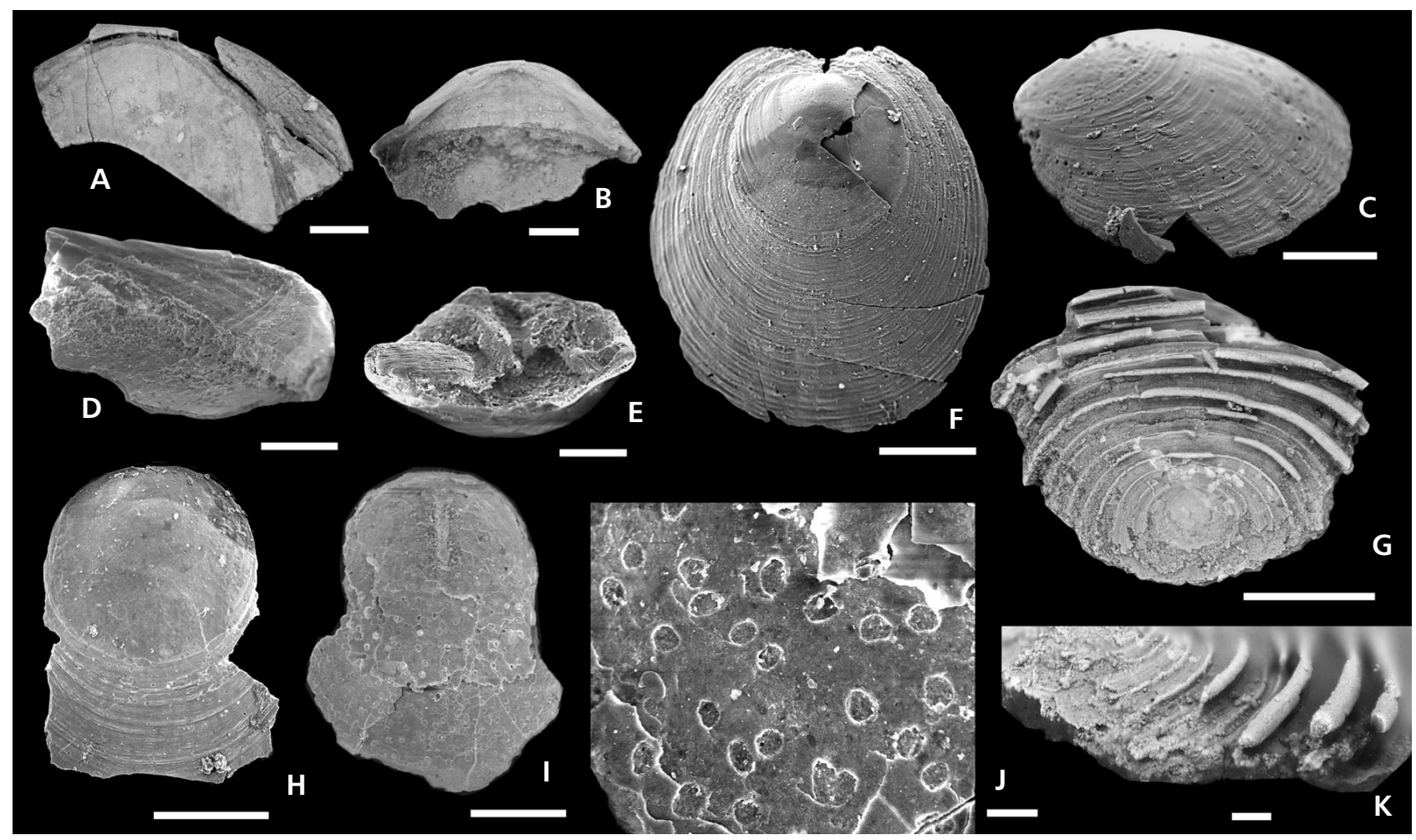

Figure 5. A - Barrandeoglossa sp., Suchomasty Limestone, Koněprusy, locality 4. • A - apex of dorsal valve, exterior, PCZCU 1924. • B, D - gen. et sp. indet., Suchomasty Limestone, Koněprusy, locality 4; apex of dorsal valve with the pseudointerarea in dorsal and oblique views, PCZCU 1925. - C, E, F, H-J - Opatrilkiella kobyla Mergl, 2009, Suchomasty Limestone, Koněprusy, locality 4; C - dorsal valve exterior, PCZCU 1927. • E - larval shell with collapsed early brephic shell, oblique view, PCZCU 1928. $\bullet$ F - ventral valve exterior, PCZCU $1926 . \bullet \mathrm{H}-$ larval shell and early brephic shell exterior, PCZCU 1929. • I, J - larval and early postlarval shell interior showing pitting, and detail of pitting, PCZCU 1930. K, L - Acrosaccus sp., Suchomasty Limestone, Koněprusy, locality 4; incomplete dorsal valve, exterior, and detail of rugellate ornament, PCZCU 1931. Bar = $1 \mathrm{~mm}(\mathrm{G})$, $200 \mu \mathrm{m}(\mathrm{A}-\mathrm{D}, \mathrm{F}, \mathrm{H}, \mathrm{I}, \mathrm{K}), 100 \mu \mathrm{m}$ (E), and $20 \mu \mathrm{m}$ (J).

Gen. et sp. indet.

Figure 5B, D

Material. - A fragment of a dorsal valve (PCZCU 1925).

Description. - One minute fragment of a dorsal valve shows a raised, massive median groove resting on the thick elevated pad high above the floor of the visceral area. The median groove is not laterally bounded by distinct propareas. Fine grooves run along shell axis on the surface of median groove.

Remarks. - The morphology of the dorsal pseudointerarea on the described fragment clearly differs from the interior of a glosselid Barrandeoglossa Mergl, 2001. Barrandeoglossa lacks a distinct median groove, which is developed in the sampled fragment. The fragment indicates a higher diversity of lingulate brachiopods at the Karbous-Orbitoproetus Community in the Herget's Quarry at Koněprusy (Havlíček \& Kukal 1990). In other sampled localities of the Suchomasty Limestone similar lingulate brachiopods were not observed.
Occurrence. - Daleje-Třebotov Formation, Suchomasty Limestone, Koněprusy, locality 4 (very rare).

Subfamily Glosselinae Cooper, 1956

\section{Genus Barrandeoglossa Mergl, 2001}

Type species. - Lingula fissurata Barrande, 1879; Motol Formation, Wenlock, Silurian; Prague Basin, Czech Republic.

\section{Barrandeoglossa? sp.}

Figure 5A

2012 Barrandeoglossa sp. - Mergl \& Vodrážková, p. 317, fig. 7A.

Material. - One fragment of dorsal valve (PCZCU 1924).

Description. - A minute fragment of the dorsal valve shows a smooth brephic shell, and fine growth lines on the 
small preserved surface of the mature shell. A thick swollen rim bordering the posterior margin of the valve is distinctly preserved. This rim typically is developed in Barrandeoglossa perneri Mergl 2001, from the Lochkov Formation (Lochkovian). A similar shell fragment with swollen rim has been described from the Třebotov Limestone by Mergl \& Vodrážková (2012).

Occurrence. - Daleje-Třebotov Formation, Suchomasty Limestone, Koněprusy, locality 4 (rare); Třebotov Limestone, $P$. partitus Zone, Choteč, Na Škrábku Quarry (rare).

Superfamily Discinoidea Gray, 1840

Family Discinidae Gray, 1840

\section{Genus Acrosaccus Willard, 1928}

Type species. - Acrosaccus schuleri Willard, 1928; Rich Valley Formation, Sandbian, Ordovician; Virginia, the USA.

Acrosaccus sp.

Figure 5G, K

2009 Acrosaccus sp. - Mergl, p. 288, fig. 6A-J.

Material. - One fragment of a dorsal valve, two small ventral valve fragments.

Description. - The fragment of the apical part of the dorsal valve indicates that the complete dorsal valve was more than $5 \mathrm{~mm}$ long, subcircular in outline, with a slightly posteriorly located apex and a posterior margin which is less rounded than the lateral margins. The valve is very weakly convex with weakly concave profile of lateral slope. The dorsal valve is almost planar in adult size. The surface is covered by concentric rugellae whose height rapidly increases with shell size. Each rugella is built by thin, subvertical lamella resting at a high angle to the shell surface, having their crests formed by thick rope-like ridge. Rugellae are separated each another by planar interspaces of almost uniform width, which is about 100 to $150 \mu \mathrm{m}$ in preserved posterior shell slope. Surfaces of the interspaces bear fine concentric fila. The first rugellae encircling the brephic shell are fine and low, but their size and crests progressively grow with shell size. The brephic shell is poorly convex, about $300 \mu \mathrm{m}$ wide.

Ventral valve has, at least in the part adjacent to the apex, a gently concave posterior slope and broadly triangular proximal part of the pedicle track.

Remarks. - The fragments represents the Acrosaccus-like discinid, which are characterized by a flattened convexo- planar to low biconvex shell having a large pedicle opening and progressively increasing size of the generally high lamellose rugellae. A similarly shaped $A$. vertex was described from the Chýnice Limestone (upper Emsian) by Mergl \& Ferrová (2009), but the lamellose rugellae of Acrosaccus sp. are higher and apparently closely crowded than those in A. vertex. Acrosaccus sp. from the Acanthopyge Limestone (Eifelian) has similar lamellose rugellae as in $A$. sp. from the Suchomasty Limestone and apparently belongs to the same or closely related species.

Occurrence. - Daleje-Třebotov Formation, Suchomasty Limestone, Koněprusy, locality 4 (rare), locality 6 (rare).

\section{Genus Chynithele Havlíček, 1996}

Type species. - Chynithele ventricona Havlíček in Havlíček \& Vaněk (1996); Zlíchov Formation, lower Emsian, Devonian; Prague Basin, Czech Republic.

\section{Chynithele intermedia sp. nov.}

Figure 6

?1879 Discina surgens Barr. - Barrande, pl. 101, case VIII, fig. 2.

2001 Chynithele ventricona Havlíček 1996. - Mergl, p. 26, pl. 20, figs 11, 13, 14, 16-21.

Holotype. - Dorsal valve figured on fig. 5B (PCZCU 515).

Type horizon. - Upper Emsian, Suchomasty Limestone, lower part of the Polygnathus serotinus Zone.

Type locality. - Koněprusy, north slope of the "Na Voskopě" hill, temporary outcrops that existed during 1985 (locality 5).

Material. - Three almost complete ventral valves, a complete dorsal valve, two juvenile dorsal valves and 20 fragments of various sizes.

Diagnosis. - Chynithele with a broad, transversely elliptical and posteriorly less rounded dorsal valve, distinct rugellate ornament in dorsal valve with overlapping crests of rugellae and moderately thickened bases of the rugellae.

Description. - The dorsal valve deeply concave, thin walled, with gently elevated and poorly convex apical part. Posterior margin is less curved than anterior and lateral margins. The maximum width is located in the posterior third of the valve.

The ventral valve is low, asymmetrically conical and transversely elliptical, with a concave anterior slope, con- 


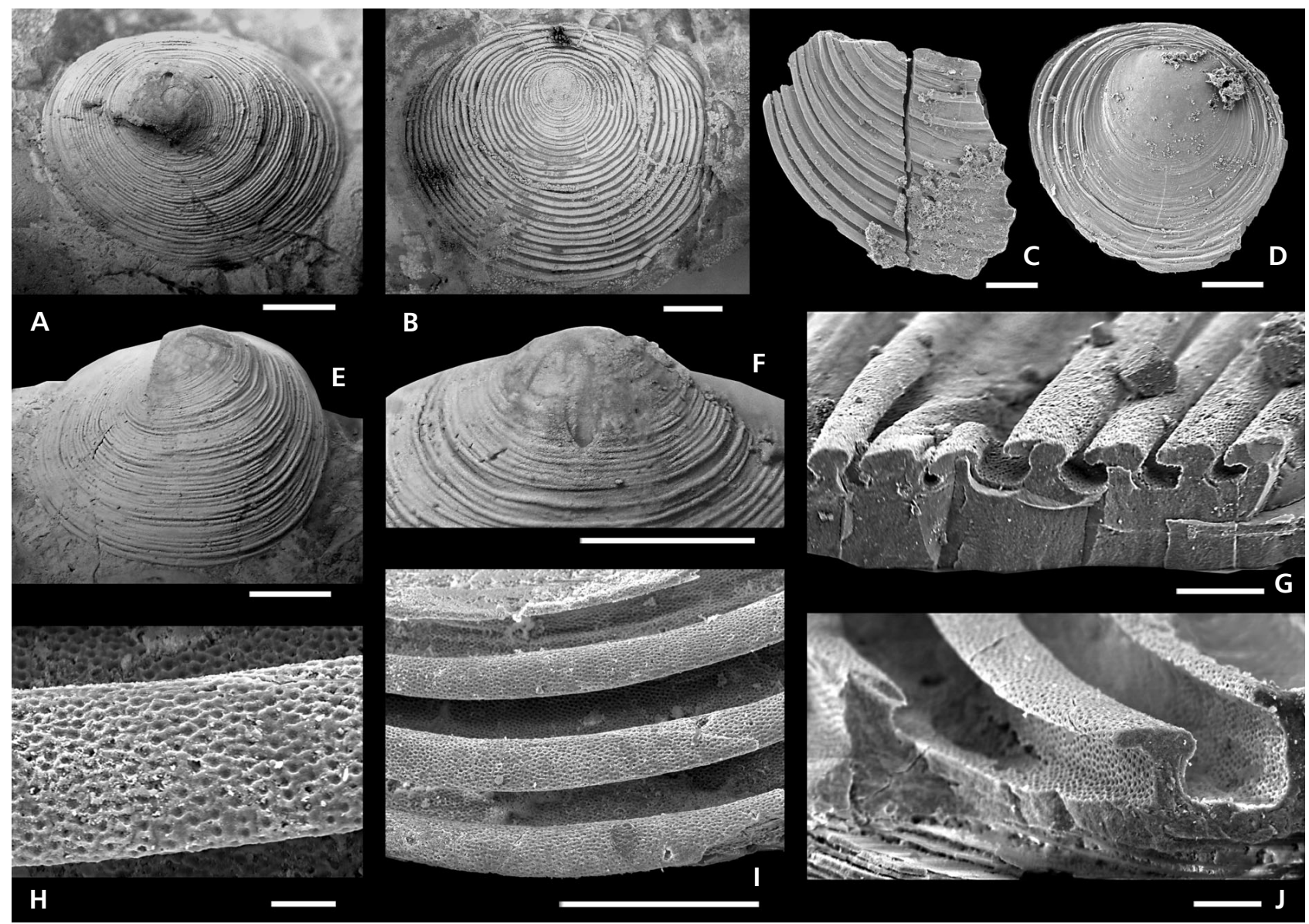

Figure 6. Chynithele intermedia sp. nov., Suchomasty Limestone, Koněprusy, localities 5 (A, B, E, F) and 6 (C, D, G-J). A, E, F- ventral valve, exterior in ventral and oblique views and detail of pedicle track, PCZCU $518 \cdot \bullet \mathrm{B}-$ dorsal valve, exterior, PCZCU $515 \cdot \bullet \mathrm{C}-$ fragment of dorsal valve, PCZCU 1922. • D - brephic shell, exterior, PCZCU 1921. - G - detail of rugellate ornamentation, PCZCU 1923. - H-J - detail of external pitted microornamentation, rugellate ornamentation, and detail of rugella, PCZCU 1920. Bar = $1 \mathrm{~mm}$ (A, B, E, F), $200 \mu \mathrm{m}$ (C, D), $100 \mu \mathrm{m}$ (G, I), $20 \mu \mathrm{m}$ (J), and $10 \mu \mathrm{m}(\mathrm{H})$.

vex posterior slope and gently convex flanks. The apex directed anteroventrally, with pedicle track facing ventrally. The pedicle track is short, shallow, with a discrete broad and gently sloping outer listrial plate and broad and shallow axial plate. The pedicle track internally continues as a long and evenly sized pedicle tube opened internally near the posterior margin of the valve. Interior of both valves is the same as in C. ventricona.

Ornamentation of the dorsal valve consists of rugellae, which are thin and low on the brephic shell, becoming much higher and wider with growth. The bases of rugellae are slightly thickened, with nearly flat topped and broad crests. The crest of each rugella forms a broad outwardly extended shelf. Interspaces are narrower to almost as wide as the crests of adjacent rugellae. The ventral valve is covered by fine rugellae which are not extended over the interspaces. Microornamentation consists of semiglobose shallow pits of 2-3 $\mu \mathrm{m}$ diameter, covering the surface of rugellae and interspaces in more or less discrete radial rows.
Remarks. - The species is intermediate between $C$. ventricona Havlíček in Havlíček \& Vaněk 1996 (Chýnice Limestone, upper Emsian) and C. amoena Mergl, 2009 (Acanthopyge Limestone, Eifelian). It shares a more transverse shell outline with $C$. amoena, but the rugellae of $C$. intermedia are more thickened, having wider bases than in $C$. amoena. The morphology of rugellae of $C$. intermedia is more similar to $C$. ventricona, but $C$. intermedia has less robust rugellae and the shelf-like extension along their crests is more extended than in C. ventricona (see Mergl \& Ferrová 2009, fig. 6P, Q). C. ventricona has a more rounded outline and more centrally located dorsal apex than $C$. intermedia and $C$. amoena. The species C. fritschi (Barrande, 1879) from the lower part of the Zlíchov Formation (lower Emsian) is poorly known (Havlíček 1998). The single known dorsal valve has a gently elongate outline and thick anterolateral margins of the visceral field unlike the transverse outline of $C$. intermedia and C. amoena. 
Occurrence. - Daleje-Třebotov Formation, Suchomasty Limestone, Koněprusy, locality 1 (rare), locality 3 (rare), locality 4 (rare), locality 5 (abundant), locality 6 (abundant).

\section{Genus Lochkothele Havlíček \& Mergl, 1988}

Type species. - Discina intermedia Barrande, 1879; Lochkov Formation, Lochkovian, Devonian; Prague Basin, Czech Republic.

Remarks. - The genus Lochkothele Havlíček \& Mergl, 1998 was erected on specimens of L. intermedia (Barrande 1879) sampled in the dark Radotín Limestone of the Lochkov Formation (Lochkovian) in the Barrandian area. The Lochkovian specimens have excellently preserved pallial markings and prominent, paired deep crescentic imprints of the central muscle scars (Havlíček \& Mergl 1988). Another diagnostic feature is the shape of the pedicle track. This is a semitubular, narrow and short slit, posteriorly terminated by an acute triangular cut. The slit internally continues as a long and evenly wide pedicle tube toward the posterior margin. This latter feature was first illustrated in L. intermedia by Mergl (2001, pl. 18, figs 5, 6). A similar pedicle slit has been observed in fragmental discinoid shells recovered from the younger stratigraphical levels of the Barrandian (Chýnice limestones: Mergl \& Ferrová 2009; Třebotov and basal Acanthopyge limestones, serotinus and partitus zones: Mergl \& Vodrážková 2012).

Lochkothele is a genus with a stratigraphic range from the Lochkovian to the early Eifelian. This genus was not recorded from the later Eifelian (Acanthopyge and Choteč limestones) (Mergl 2009).

\section{Lochkothele rugellata sp. nov.}

Figure 7

2001 Lochkothele sp. - Mergl, p. 45, pl. 18, fig. 13.

2009 Lochkothele sp. - Mergl \& Ferrová, p. 532, fig. 7.

2012 Lochkothele sp. - Mergl \& Vodrážková, p. 320, figs 7O-Q.

Holotype. - Ventral valve figured on Fig. 7B, C, H (PCZCU 1934).

Type horizon. - Upper Emsian, Suchomasty Limestone, lower part of Polygnathus serotinus Zone.

Type locality. - Koněprusy, "Na Voskopě” hill, neptunian dyke in $\mathrm{W}$ wall of the quarry (locality 7).

Material. - Three almost complete ventral valves, and six fragments of ventral valve from the Suchomasty Limestone.

Diagnosis. - Lochkothele with distinct rugellate ornamentation and weak impressions of the pallial markings.

Description. - The shell is $8 \mathrm{~mm}$ wide, thin to medium-thick walled, circular in outline, with the maximum width situated at shell mid-length. The ventral valve posterior slope, anterior slope and flanks are evenly sloping. Shell margins are evenly rounded. The pedicle track is a narrow, simple, U-shaped semitubular slit, evenly broad along its entire $0.8 \mathrm{~mm}$ length. The slit continues as a long cylindrical internal tube that is opened near the posterior margin. The width of the pedicle tube is uniform along its whole length.

Ventral valve interior shows deeply impressed, crescentic central scars posterior to, and a pair of small circular imprints anterior to the apical pit. A low broadly rhomboidal callosity is located anterior to the apex, but is without any distinct border.

Ornamentation consists of fine concentric rugellae arranged in regular intervals. The profile of the rugella is low semicircular, with a broad base. Interspaces are depressed, flat, wider that rugellae. There are 6 to 8 rugellae posterolaterally per $1 \mathrm{~mm}$. Size and distributional pattern of rugellae are uniform over the entire valve. Interspaces are much wider than rugellae with ornament of weak growth lines. Dorsal valve is unknown. Microornamentation formed by small, evenly distributed and rather distant pits, with smooth interspaces. Diameter of pits is around $2 \mu \mathrm{m}$.

Remarks. - The new species differs from the type species L. intermedia (Lochkovian, Radotín Limestone; Prague Basin) by more prominent rugellate ornament of the ventral valve and weakly impressed pallial markings. An unnamed species $L$. sp. from the Chýnice Limestone (upper Emsian) (Mergl \& Ferrová 2009) and L. sp. from the Třebotov Limestone (upper Emsian) and the basal Acanthopyge Limestone (upper $P$. serotinus Zone) (Mergl \& Vodrážková 2012) likely belong to the same species.

Occurrence. - Zlíchov Formation, Chýnice Limestone, Bubovice (Čeřinka) (Mergl \& Ferrová 2009); DalejeTřebotov Formation, Suchomasty Limestone, Koněprusy, locality 1 (rare), locality 4 (rare), locality 5 (rare), locality 6 (rare), locality 7 (rare).

Dimensions. -

$\begin{array}{lllll}\text { Specimen No. W }(\mathrm{mm}) & \mathrm{L}(\mathrm{mm}) & \mathrm{H}(\mathrm{mm}) & \mathrm{W} / \mathrm{L} & \mathrm{H} / \mathrm{L}\end{array}$

$\begin{array}{llllll}\text { PCZCU } 1933 & 8.0 & 7.6 & 2.6 & 1.05 & 3.08\end{array}$

$\begin{array}{llllll}\text { PCZCU } 1934 & 8.0 & 7.5 & 2.5 & 1.07 & 3.02\end{array}$




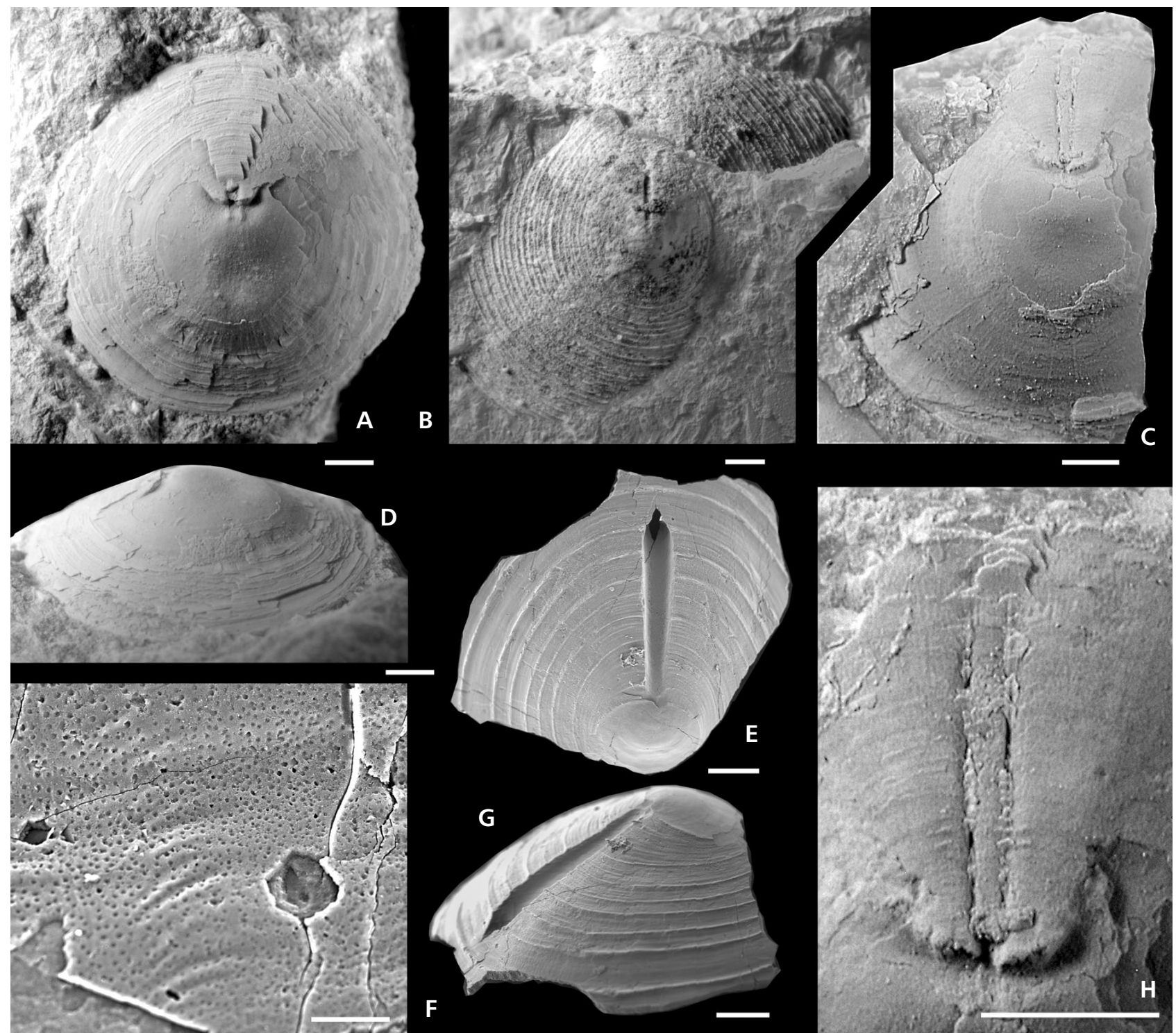

Figure 7. Lochkothele rugellata sp. nov., Suchomasty Limestone, Koněprusy, localities 5 (A, D), 6 (E-G), and 7 (B, C, H) • A, D - ventral partly exfoliated valve, PCZCU 1933. B , C, H - ventral valve exterior and its internal mould, holotype, PCZCU 1934 . E-G - incomplete ventral valve, and detail of microornamentation, PCZCU 1932. Bar $=1 \mathrm{~mm}(\mathrm{~A}-\mathrm{D}, \mathrm{H}), 200 \mu \mathrm{m}(\mathrm{E}, \mathrm{G})$, and $20 \mu \mathrm{m}(\mathrm{F})$.

\section{Genus Opatrilkiella Mergl, 2001}

Type species. - Opatrilkiella minuta Mergl, 2001; Požáry Formation, Př́idolí, Silurian; Prague Basin, Czech Republic.

\section{Opatrilkiella kobyla Mergl, 2009}

Figure 5C, E, F, H-J

2001 Opatrilkiella (?) sp. B. - Mergl, p. 30, pl. 24, fig. 10.

2009 Opatrilkiella kobyla sp. nov. - Mergl, p. 290, figs $8,9$.

2009 Opatrilkiella kobyla Mergl, 2009. - Mergl \& Ferrová, p. 532, figs 8,9 .
2012 Opatrilkiella kobyla Mergl, 2009. - Mergl \& Vodrážková, p. 322, fig. 7J, L-N.

Material. - Three complete valves, and ten incomplete brephic and larval valves.

Remarks. - Specimens from the Herget's Quarry (locality 3) show circular pits on the interior of the brephic shell (Fig. 5I, J). These pits are preserved only on interior of the shell and are not present on the shell exterior. It is evident that these pits are not borings on an empty shell. Pits penetrate deep into two or three lamellae of the shell wall and are regularly spaced. Outline of pits is almost circular, with a diameter around $15 \mathrm{~mm}$. The pits are similar 
to the davisate pits of lingulates, but are much smaller and more regularly spaced.

Some extracted shells from the same locality are preserved as larval shells with a few attached early growth bands of the postlarval shell. One valve (Fig. 5E) displays a postlarval shell collapsed into the internal space of the larval shell, indicating that the early postlarval shell was remarkably flexible.

Morphology of the adult shell is the same as specimens described from the Acanthopyge Limestone (Mergl 2009) and the Chýnice Limestone (Mergl \& Ferrová 2009), with microornamentation of fine folds on the postlarval shell exterior.

Occurrence. - Zlíchov Formation, Chýnice Limestone, Bubovice (Čeřinka) (Mergl \& Ferrová 2009); Daleje-Třebotov Formation, Suchomasty Limestone, Koněprusy, locality 4 (abundant), locality 6 (rare); Třebotov and Choteč limestones, Praha-Barrandov, Praha-Holyně and Chýnice (Jelínek mill Quarry) (Mergl \& Vodrážková 2012); Acanthopyge Limestone, Koněprusy (Preisler's Quarry) (Merg1 2009).

\section{Genus Praeoehlertella Mergl, 2001}

Type species. - Praeoehlertella umbrosa Mergl, 2001; Praha Formation, Pragian, Devonian; Prague Basin, Czech Republic.

\section{Praeoehlertella lukesi sp. nov.}

Figure 8

Holotype. - Ventral valve figured on Fig. 8A-E (PCZCU 1938).

Type horizon. - Upper Emsian, Suchomasty Limestone, Polygnathus serotinus Zone.

Type locality. - Koněprusy, N slope of the "Na Voskopě" hill, temporary outcrops that existed in 1985 (locality 5).

Name. - After Pavel Lukeš, an outstanding specialist on Czech Devonian tentaculites.

Material. - One ventral valve, one dorsal valve, and numerous small shell fragments.
Diagnosis. - Praeoehlertella with ornamentation of closely spaced uniformly sized rugellae.

Description. - The shell is ventribiconvex, with a moderately thick shell wall, $7 \mathrm{~mm}$ wide as measured at maximum width, broadly oval in outline, with the maximum width situated slightly posterior to the midlength, approximately at level of the ventral apex.

Dorsal valve is very low, asymmetrically conical. Dorsal apex is situated at $20 \%$ of the valve length. Posterior margin less rounded than anterior and lateral margins.

Ventral valve is depressed conical. Ventral apex is situated at $40 \%$ of valve length. Valve margins are evenly curved. Posterior slope is gently convex, with a weakly depressed triangular sector bordering the pedicle track. Anterior slope is weakly concave, flanks are straight. The pedicle track is formed by a narrow, deep and ventrally opened slit. Anterior half of the slit is somewhat broader, deep, V-shaped in a transverse profile (Fig. 8C). Posterior half of the tracks is tubular, ventrally opened by a narrow slit extended towards the posterior margin.

Ventral valve interior has a broad ridge that corresponds to the pedicle track. Large paired crescentic central scars are located posterior to the apical chamber. A pair of a smaller muscle scars is weakly impressed at the posterolateral pits of the central scars. Third pair of small scars is lateral to the apical chamber and likely belongs to the middle lateral muscles. Dorsal valve interior has a shallow apical pit and a short and low median ridge. Muscle scars are unknown due poor preservation of the shell.

Ornamentation consists of regular rugellae becoming higher and wider with shell growth. Particular rugella usually completely encircle the shell apex. New incomplete rugellae less commonly originate by implantation on the surface of the interspaces or disappear on the flanks. The early rugellae are very fine and appear on the early postlarval shell. There is 17-18 rugellae per $1 \mathrm{~mm}$ anteromedianly in large shells. Rugellae have a semicircular profile, rounded crests, maximum width at the base, and are separated from each another by concave interspaces, which are $40-80 \%$ as wide as bordering rugellae. Shape of rugellae on the posterior slope of shell differs from rugellae on flanks. The former are generally higher, more variable in size, and their course is less rounded. Rugellae bordering the pedicle track disappear before the edge of pedicle track in the anterior, wider part of the track (Fig. 8F), but rugellae are extended over the

Figure 8. Praeohlertella lukesi sp. nov., Suchomasty Limestone, Koněprusy, localities 4 (J, K), 5 (A-E, H, I, L), and 6 (F, G, M). • A-E-holotype, ventral valve internal mould, exterior, detail of the pedicle track, and internal mould and exterior in oblique views, PCZCU 1938 . $\bullet$ F, M - fragment of ventral valve and details of its microornamentation, PCZCU $1936 . \bullet \mathrm{G}-$ fragment of dorsal ventral showing larval shell, PCZCU 1937 . $\bullet \mathrm{H}, \mathrm{I}, \mathrm{L}-$ dorsal valve interior, exterior and detail of posterior slope, PCZCU 1939. • J, K - fragment of dorsal valve and detail of rugellate ornamentation, PCZCU 1935. Bar $=1 \mathrm{~mm}(\mathrm{~A}-\mathrm{E}, \mathrm{H}-\mathrm{J}, \mathrm{L}), 200 \mu \mathrm{m}(\mathrm{F}, \mathrm{G}, \mathrm{K})$, and $20 \mu \mathrm{m}(\mathrm{M})$. 
Michal Mergl \& Andrea Jiménez-Sánchez • Lingulate brachiopods from the Suchomasty Limestone (upper Emsian) of the Barrandian

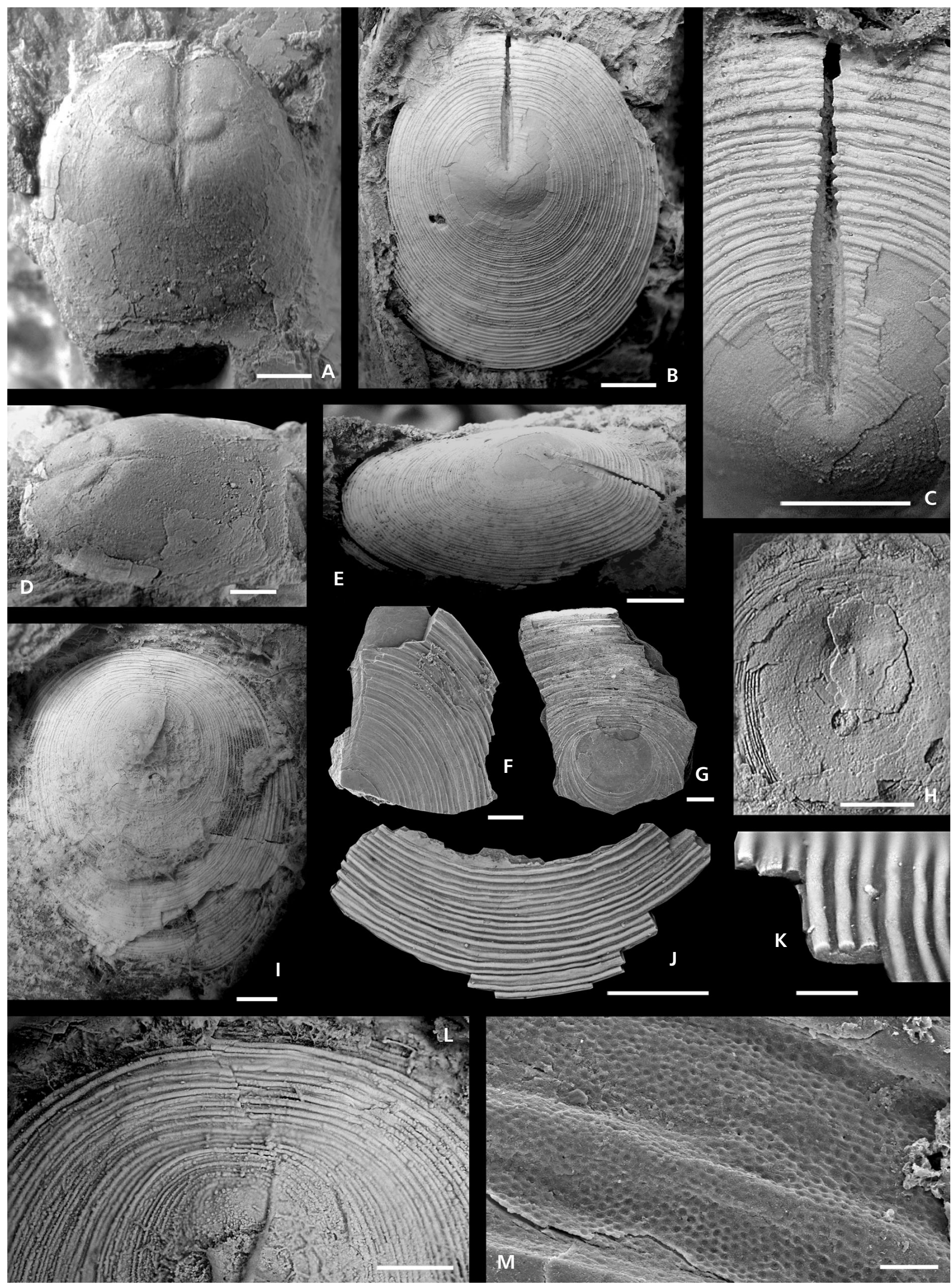


edge of the track in the posterior part of the track (Fig. 8C). Microornamenation consist of fine, shallow circular semiglobular pits separated by narrow ridge-like interspaces (Fig. 8M). Diameter of pits is around $4 \mu \mathrm{m}$. Pits are uniform in size, with prevalent honeycomb-like arrangements.

Remarks. - The new species differs from P. umbrosa Mergl, 2001 of Pragian age (Prague Basin) by its more regular ornamentation. Praeohlertella umbrosa has several coarser rugellae separated by broad strips, covered only by fine concentric lines. The early Silurian species P. georgiana Mergl, 2001 differs by its unevenly rugellate ornament and more centrally situated dorsal apex. The narrow triangular pedicle track present in both described species of the genus (Mergl 2001) is also present in the new species, but its walls on the posterior part of the track are almost vertical and hidden below the extension of rugellae over the pedicle track. A restriction of mineralization along the shell axis below the pedicle track is evident from a line visible on the ventral face of the internal ridge on the posterior part of the ventral valve (Fig. 8A). An unnamed species $P$. sp. of the early Emsian age (Chýnice Limestone; Prague Basin) described by Mergl \& Ferrová (2009) differs from P. lukesi by a weakly rugellate exterior.

Occurence. - Daleje-Třebotov Formation, Suchomasty Limestone, Koněprusy, locality 3 (rare), locality 4 (rare), locality 5 (rare), locality 6 (rare).

Order Acrotretida Kuhn, 1949

Superfamily Acrotretoidea Schuchert, 1893

Family Biernatidae Holmer, 1989

\section{Genus Havlicekion Mergl, 2001}

Type species. - Havlicekion splendidus Mergl, 2001; Praha Formation, Pragian, Devonian; Prague Basin, Czech Republic.

\section{Havlicekion frydai Mergl \& Ferrová, 2009}

Figure 9

2009 Havlicekion frydai sp. nov. - Mergl \& Ferrová, p. 540 , figs $13,14 \mathrm{~J}, \mathrm{~K}$.
Material. - Ten dorsal valves, ten ventral valves, numerous small fragments.

Remarks. - Material from the Suchomasty Limestone is morphologically indistinguishable from the type material coming from the Chýnice Limestone illustrated by Mergl \& Ferrová (2009). The mode of preservation in the Suchomasty Limestone is less favourable and specimens are usually much fragmental. The fine microornament present on rugellae of the type specimens (Mergl \& Ferrová 2009, fig. 13P) was not ascertained in specimens from the Suchomasty Limestone. However, the structure of pitting on the larval shell, with larger flat-based circular and lunate pits and smaller hemisphaerical pits has been observed in new specimens from the Suchomasty Limestone (Fig. 9M, N) and justified attribution of these specimens to $H$. frydai Mergl \& Ferrová (2009).

Interior of the ventral valve shows deeply impressed long and anteriorly converging distal branches of vascula media and deeply impressed epithelian cells moulds (Fig. 9F). Similar clusters of deeply impressed epithelian cell moulds bordering anteriorly the muscle imprints are also present on the dorsal valve interior (Fig. 9J, K).

Occurrence. - Zlíchov Formation, Chýnice Limestone, Bubovice (Čeřinka) (Mergl \& Ferrová 2009); DalejeTřebotov Formation, Suchomasty Limestone, Koněprusy, locality 2 (rare), locality 3 (abundant), locality 4 (abundant), locality 6 (rare).

\section{Genus Opsiconidion Ludvigsen, 1974}

Type species. - Opsiconidion arcticon Ludvigsen, 1974; Emsian, Devonian; Yukon, Canada.

\section{Opsiconidion coralinus Mergl \& Ferrová, 2009}

Figure 10

2009 Opsiconidion coralinus sp. nov. - Mergl \& Ferrová, p. 544, figs 14A-I, M-O.

Material. - Ten dorsal valves, five ventral valves and numerous fragments.

Remarks. - Although shells from the Suchomasty Limestone are poorly preserved they may be well compared with

Figure 9. Havlicekion frydai Mergl \& Ferrová, 2009, Suchomasty Limestone, Koněprusy, localities 2 (H, K), 4 (D), and 6 (A-C, E-G, I, J, L-O). - A, E - ventral valve exterior in posteroventral and lateral views, PCZCU $1945 . \bullet B, F-$ ventral valve exterior and interior, PCZCU 1944 • C - ventral valve in apical view, PCZCU 1947. • D - ventral valve exterior in anterior view, PCZCU $1946 . \bullet \mathrm{G}, \mathrm{J}$ - dorsal valve interior, PCZCU $1940 \cdot \bullet \mathrm{H}, \mathrm{K}-$ dorsal valve interior, PCZCU 1941. $\bullet$ I, M - dorsal valve exterior and detail of its larval shell, PCZCU 1942. $\bullet$, N, O - dorsal valve exterior, detail of its larval shell, and anterior view, PCZCU 1943. Bar $=100 \mu \mathrm{m}(\mathrm{A}-\mathrm{L}, \mathrm{O})$, and $50 \mu \mathrm{m}(\mathrm{M}, \mathrm{N})$. 


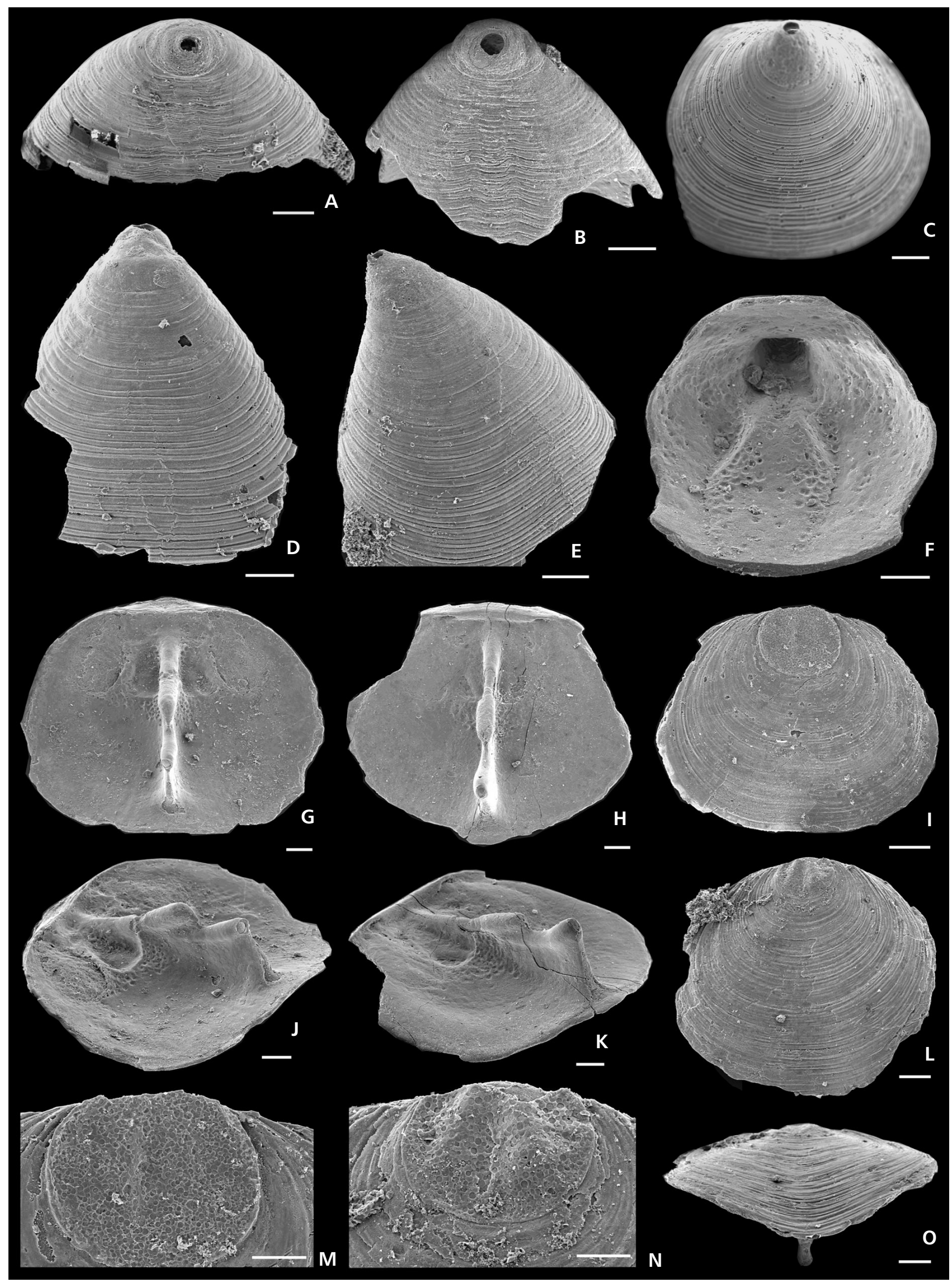


specimens from the Chýnice Limestone. Unlike to associated biernatid Havlicekion frydai Mergl \& Ferrová, 2009, the species $O$. coralinus Mergl \& Ferrová, 2009 has weaker external ornamentation, almost ventrally directed pedicle opening and subpentagonal dorsal valve with weaker upper rod on the dorsal septum. Available fragments indicate that the adult shell of $O$. coralinus reachs $1.5 \mathrm{~mm}$ height and was larger than the largest shells of $H$. frydai. Apart of the ornamentation, Opsiconidion differs from associated Havlicekion by the shape of ventral valve. Opsiconidion ventral valve is bullet-like, with very weakly conical, weakly diverging sided slopes in the later growth. Microornamentation of the larval shell consist on flat-bottomed circular pits, which do not overlap one another; lunate pits developed in $H$. frydai are uncommon in $O$. coralinus.

Occurrence. - Zlíchov Formation, Chýnice Limestone, Bubovice (Čeřinka) (Mergl \& Ferrová 2009); DalejeTřebotov Formation, Suchomasty Limestone, Koněprusy, locality 4 (abundant), locality 6 (rare).

Superfamily Siphonotretoidea Kutorga, 1848

Family Siphonotretidae Kutorga, 1848

\section{Genus Orbaspina Valentine \& Brock, 2003}

Type species. - Orbaspina gelasinus Valentine \& Brock, 2003; Wenlock, Silurian; New South Wales, Australia.

\section{Orbaspina sp.}

Figure 11

2001 Schizambonine sp. B. - Mergl, p. 38, pl. 36, figs 11-14.

2012 Orbaspina sp. - Mergl \& Vodrážková, p. 324, fig. 10A-C.

Material. - One incomplete dorsal valve.

Description. - The dorsal valve is subcircular, with posteriorly pointed apex. The valve is moderately convex transversely and axially, with flattened narrowly triangular median sector. The shell bears concentric rows of asymmetrical pits, uniformly sized over the whole shell, best preserved in small part of the available valve. Most of the surface is exfoliated and pits are less distinct. Pits are 15 to $20 \mu \mathrm{m}$ wide, some almost fused together, transversely elliptical and deepest in their posterior part. The dorsal valve interior has a short and deeply concave pseudointerarea.

Remarks. - The shell is very similar and its exterior lacks spines as the shell figured by Mergl \& Vodrážková (2012).
The dorsal valve with several preserved spines figured by Mergl (2001) likely belongs to the same species.

Occurrence. - Daleje-Třebotov Formation, Suchomasty Limestone, Koněprusy, locality 6 (very rare); Třebotov Limestone, lowermost $P$. partitus Zone, Chýnice (Jelínek mill Quarry) (Mergl \& Vodrážková 2012), Praha-Holyně (Prastav Quarry).

\section{Conclusions}

\section{Causes and impact of diminutive size of peri-reefal lingulates}

Attempt to observe lingulate brachiopods in white bioclastic reef Koněprusy Limestone (Pragian) as well as white bioclastic beds of the Acanthopyge Limestone (Eifelian) with use of the solution of acetic acid were not successful in the Barrandian area. All samples were barren. All lingulates yet known from the Koněprusy Limestone (Barrande 1879, Mergl 2001) were collected by hammering and their finds are incidental. This indicates that lingulate brachiopods in reef limestone of Pragian to Eifelian age are very rare unlike to extremely abundant crinoids (Prokop 1987), bryozoans, rhynchonellid, strophomenid, atrypid, spiriferid and other, generally costate rhynchonelliform brachiopods (Havlíček \& Vaněk 1998, Havlíček 1998). The lingulates were extremely scarce component among reef biota.

Set of new data about peri-reefal lingulate brachiopods (Havlíček 1998; Mergl 2001, 2009; Mergl \& Ferrová 2009; Mergl \& Vodrážková 2012) indicates, that Emsian to Eifelian lingulate brachiopods in the Barrandian area are mainly represented by micromorphous linguloids, discinoids, biernatids and siphonotretids. Small-sized lingulates, represented almost exclusively by discinoids are comparatively rare. There are none medium to large-sized infaunal linguloids or large discinoids, which are characteristic for siliciclastic shelves of the Devonian age elsewhere (see Boucot 1975, Boucot et al. 2001). In the peri-reef environment was no firm argillaceous substrate necessary for burrowing habitat of linguloids (Emig 1997), but only unstable calcareous sand and mud, large bioclasts or hardgrouds. Small linguloids could accommodate other ecospaces as corals or stromatoporoids (Newall 1970, Tapanila \& Holmer 2006).

Despite only moderate diversity and small size of perireefal Emsian-Eifelian lingulates in the Barrandian, their morphological disparity is remarkable. There are discinoids with subplanar (Acrosaccus), low conical (Schizotreta, Praeohlertella) to high conical (Chynithele) ventral valves. Discinoids have posteriorly open (Opatrilkiella, Praeohlertella), or closed large (Acrosaccus) to diminutive 


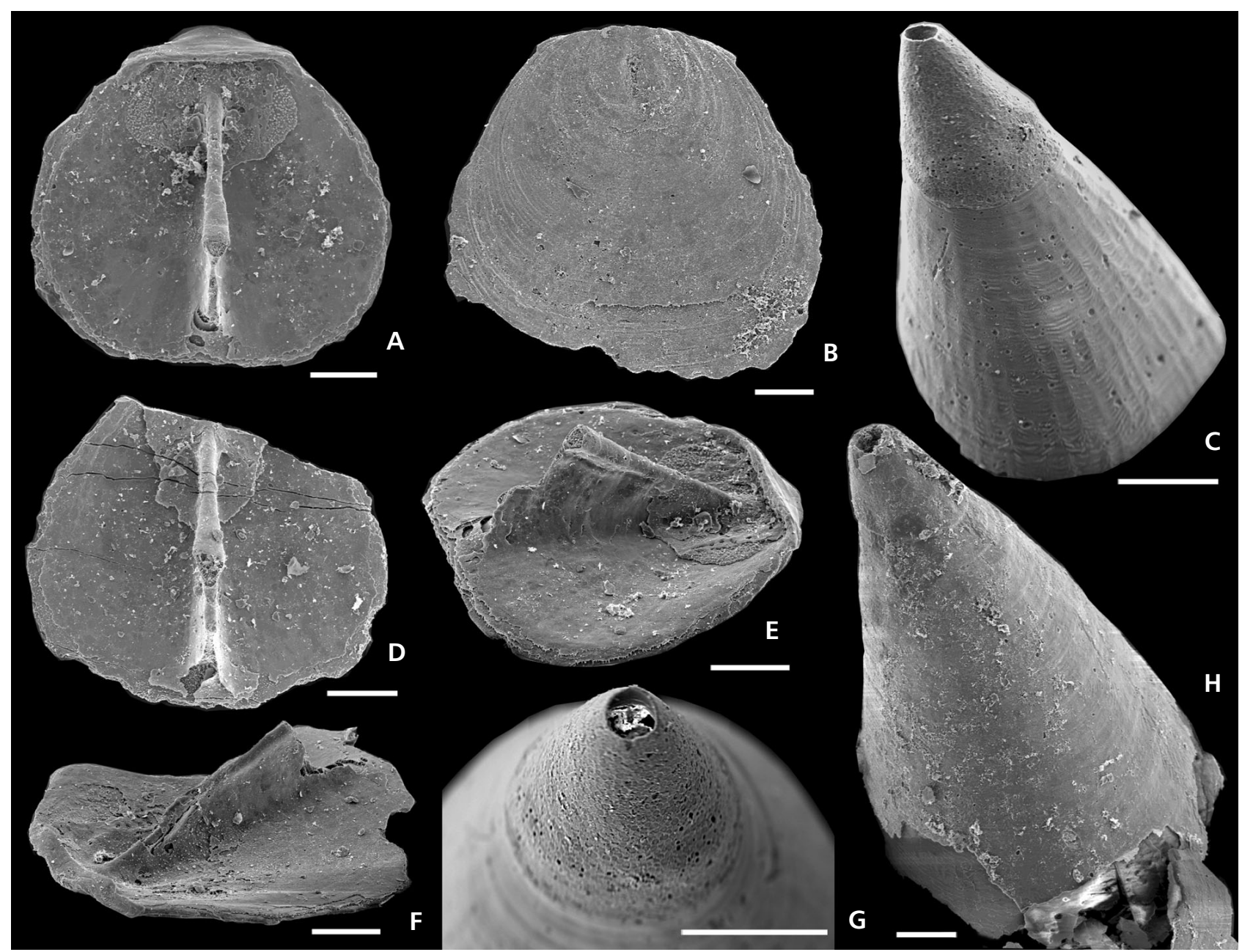

Figure 10. Opsiconidion corallinus Mergl \& Ferrová 2009, Suchomasty Limestone, Koněprusy, localities 2 (A, D-F, H), and 4 (C, G) and 6 (B). - A, E - dorsal valve interior and its oblique view, PCZCU $1948 \cdot \bullet$ B - dorsal valve exterior, PCZCU $1950 \cdot \bullet C, G$ - ventral valve in lateral view and detail of the apex, PCZCU 1951. D , F - dorsal valve interior and its oblique view, PCZCU 1949. • H - ventral valve exterior lateral view, PCZCU 1952. $\operatorname{Bar}=100 \mu \mathrm{m}$.

pedicle track (Chynithele). Discinoids are epibenthic fixo-sessile brachiopods (Emig 1997), often with cryptic habitat on or inside empty shells (Lockley \& Antia 1980, LaBarbera 1985, Kato 1996, Bassett et al. 2009) or on the underside of boulders. Small size of lingulates (Kosagittella, Microbolus) and shape of the pedicle groove support speculation about their epibenthic and cryptic habitat in small cavities and interspaces between large bioclasts. Micromorphic size with few spines of siphonotretid Orbaspina corroborates suggestion about cryptic habitat in small cavities of bioclasts, with already reduced supporting function of hollow spines in contrast to their Ordovician ancestors (Wright \& Nõlvak 1997). A suggested mode of life of biernatids Havlicekion and Opsiconidion, from interstitial habitat inside crinoid sand, inside lime-mud to epiphytic on floating algal threads were discussed by Mergl \& Vodrážková (2012). This disparity indicates that lingulates occupied diverse micro-niches on or near sea-floor but likely were less successful and were highly stressed by food competition with associated rhynchonelliform brachiopods, stromatoporoids and corals. The rhynchonelliform brachiopods were mostly small to medium sized but highly effective spire bearers (smooth shelled spiriferids, atrypids and pentamerids; Havlíček \& Kukal 1990). Another competitive group could be small crinoids and microcrinoids (Pisocrinus, Tiaracrinus, Aureocrinus, Pygmaeocrinus, Ramacrinus), a groups common in a deeper flanks of the reef (Prokop 1987). Is it probable, that competition for the food was critical factor for lingulates in suggested meso- to oligotrophic waters of reef periphery. Food competition together with the increased importance of predation and grazing by molluscs and vertebrates were compensated by a cryptic habitat and diminution of body size in diverse clades of lingulates. One may speculate that the body miniaturization is also adaptation for habitat on higher tier level, e.g. dead arms and 


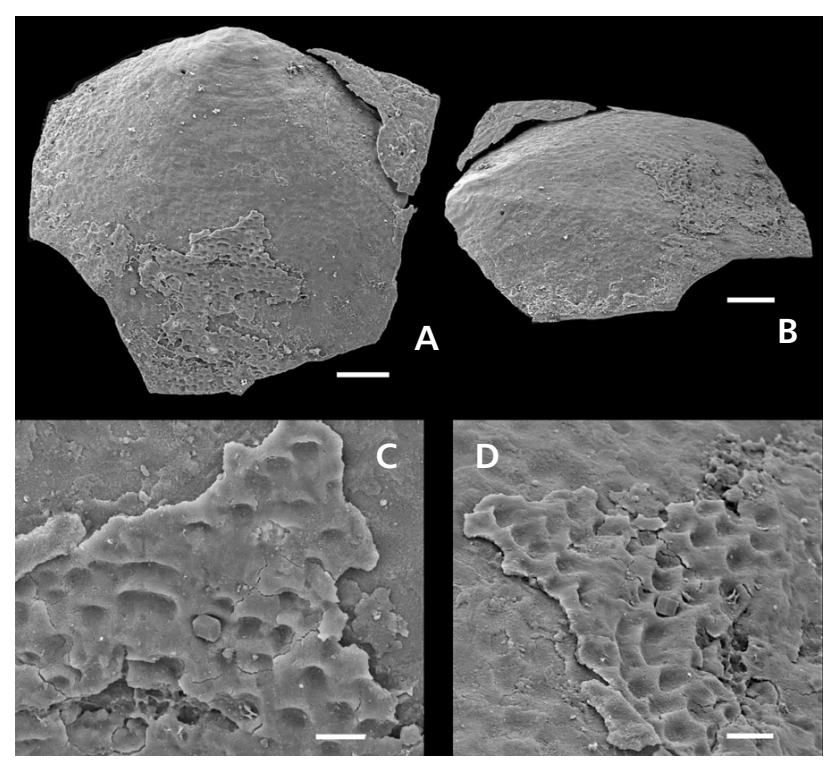

Figure 11. Orbaspina sp., Suchomasty Limestone, Koněprusy, locality 6. A-D - dorsal valve in dorsal and oblique views, and details of external ornamentation, PCZCU 1919. Bar $=100 \mu \mathrm{m}(\mathrm{A}, \mathrm{B})$, and $20 \mu \mathrm{m}(\mathrm{C}, \mathrm{D})$.

underside of corals, or around oscular openings of sponges. This diminution is evident even in originally small-sized biernatids. The Silurian and Devonian Opsiconidion and Havlicekion are generally smaller than their Ordovician relatives (biernatids, torynelasmatids).

Miniaturization developed as an evolutionary novellity in the early Devonain was possibly advantageous for lingulates on periphery of reefs. However, the crisis of reef environment in the upper Devonian heavily affected not only reef-building invertebrates but also diminutive lingulates. Records of biernatids and siphonotretids vanish in the Upper Devonian (Holmer \& Popov 2000). Morphological disparity of discinoids decreased at the end of the Devonian, with only the convexo-planar design of the discinid shell persisted to the Recent.

\section{Ancestors of the Emsian-Eifelian peri-reefal lingulates}

The main morphological features of genera present in the Chýnice, Suchomasty and Acanthopyge limestones originated as early as the Ordovician or, at least, in the Silurian. Four Emsian and Eifelian species of Chynithele are without doubt derived from the genus Ivanothele, which is known from limestone of Wenlock age of Gotland (Mergl 2010) and tuffaceous limestone of Ludlow age in the Barrandian (Mergl 1996, 2001). Lochkothele is known already from the Wenlock (Mergl 2006), with the next report from the Lochkovian (Havlíček \& Mergl 1988). Praeohlertella is known from the Llandovery (Mergl 2001). The earliest known Opsiconidion is of Middle Ordovician age (Sutton et al. 2000). Havlicekion has been reported from the Wenlock (Mergl 2001). The siphonotretid Orbaspina retains very ancestral (Furongian) characters of the siphonotretid morphology (Valentine 2006), with morphologically related species from the Darriwilian (Mergl 2001).

The obolid Kosagittella is known from the Ludlow (see in discussion of the genus above). The origin of the Eifelian genus Microbolus is very enigmatic. There are some reports of micromorphic obolids in the Cambrian and Ordovician strata (Mergl 2002), but no micromorphic obolids are reported in the Silurian or Early Devonian.

A lingulate brachiopod Paterula has been reported in red micritic limestone of the Chýnice Limestone, but is unknown from the Suchomasty and Acanthopyge limestones. It is very rare genus in the Chýnice Limestone, until recently known only from a few fragments (Mergl \& Ferrová 2009). This genus, whose first records are from the Dapingian (Mergl 1999), is a typical deeper water lingulate. It is known from many outer shelf sites worldwide (for a review see Mergl 1999). In the Barrandian, there are almost continuous records of this genus from the Dapingian to the Eifelian, but always in deeper water lithofacies, both argillaceous and calcareous. Paterula was ascertained, but very rarely (Mergl \& Ferrová 2009) in basinward periphery of biohermal or reefal limestones of the Silurian or Devonian age. This is wholy consistent with its suggested deeper water habitat. This ecospace is evidenced also by Lenz (1993) observations of Paterula specimens attached around the oscular opening of a hyalosponge. The latest record of the genus comes from dark limestones of the Choteč Limestone (early Eifelian), from which $P$. holynensis Mergl, 2001 was described.

\section{Acknowledgements}

The author is greatly indebted to J. Nebesářová, J. Vaněček, and T. Bílý (Academy of Science of the Czech Republic, České Budějovice) for help with the SEM study and to S. Vodrážková (Czech Geological Survey) for supplying conodont data. We are also indebted to R. Blodgett, L. Popov, and J. Frýda for valuable comments to the manuscript. This study was supported by a grant of the Grant Agency of the Czech Republic GAČR No. P210-12-2018.

\section{References}

BARRANDE, J. 1847. Ueber die Brachiopoden der silurischen Schichten von Böhmen. I. Teil. Naturwissenchachtliche Abhandlungen 2, 337-475. W. Haidinger, Wien.

BARRANDE, J. 1848. Ueber die Brachiopoden der silurischen Schichten von Böhmen. II. Teil. Naturwissenchachtliche Abhandlungen 2, 155-256. W. Haidinger, Wien.

BARRANDE, J. 1852. Systême silurien du centre de la Bohême. I. Trilobites. 1100 pp. Prague \& Paris. 
BarRande, J. 1879. Systême silurien du centre de la Bohême. Ière partie. Recherches paléontologiques. Vol. 5. Classe des Mollusques. Ordre des Brachiopodes. 226 pp. Prague \& Paris.

Bassett, M.G., Popov, L.E., Aldridge, R.J., Gabbott, S.E. \& THERON, J.N. 2009. Brachiopoda from the Soom Shale Lagerstätte (upper Ordovician, South Africa). Journal of Palaeontology 83(4), 614-623. DOI 10.1666/08-136.1

Berkyová, S. 2004. Middle Devonian Tentaculitoidea from the late generation of fillings of the neptunian dyke in the Koněprusy area (Prague Basin, Czech Republic). Journal of the Czech Geological Society 49(3-4), 147-155.

Berkyová, S. 2009. Lower-Middle Devonian (upper EmsianEifelian, serotinus-kockelianus zones) conodont faunas from the Prague Basin, the Czech Republic. Bulletin of Geosciences 84(4), 667-686. DOI 10.3140/bull.geosci.1153

Boucot, A.J. 1975. Evolution and extinction rate controls. 427 pp. Elsevier, Amsterdam, Oxford, New York.

Boucot, A.J., Rowell, A.J., Racheboeuf, P., Pereira, E., Gonçalves de Melo, J.H. \& Peixoto de Siqueira, L. 2001. Position of the Malvinokaffric Realm's northern boundary (Early Devonian) based on newly discovered brachiopods from the Parecis Basin (Brazil). Journal of the Czech Geological Society 46, 109-120.

Chlupáč, I. 1955. Stratigraphical study of the oldest Devonian beds of the Barrandian. Sborník Ústředního ústavu geologického, Oddíl geologický 21(2), 91-224.

CHLuPÁČ, I. 1956. Nové poznatky o stratigrafii středočeského devonu. Věstník Ústředního ústavu geologického 31, 233-243.

CHLuPÁČ, I. 1957. Facial development and biostratigraphy of the Lower Devonian of Central Bohemia. Sborník Ústředního ústavu geologického, Oddíl geologický 23, 369-485.

CHLuPÁČ, I. 1959. Facial development and biostratigraphy of Daleje Shales and Hlubočepy Limestones (Eifelian) in the Devonian of Central Bohemia. Sborník Ústředního ústavu geologického, Oddíl geologický 24, 446-511.

ChlupÁč, I. 1977. The phacopid trilobites of the Silurian and Devonian of Czechoslovakia. Rozpravy Ústředního ústavu geologického 23, 1-172.

Chlupáč, I. 1983. Trilobite assemblages in the Devonian of the Barrandian area and their relations to palaeoenvironments. Geologica et Palaentologica 17, 43-73.

Chlupáč, I. 1984. Devon Zlatého koně. Český kras 9, 17-27.

ChlupáČ, I. 1994. Devonský útes u Koněprus. Vesmír 73, 618-623.

ChLupáč, I. 1996. Neptunian dykes in the Koněprusy Devonian: Geological and palaeontological observations. Věstník Českého geologického ústavu 71(3), 193-208.

CHLupÁČ, I. 1998. K faciím a stratigrafii spodnodevonského útesového komplexu u Koněprus. Věstník Českého geologického ústavu 73(1), 1-13.

Chlupáč, I. 1998. Devonian, 101-133. In Chlupáč, I. et al. Palaeozoic of the Barrandian (Cambrian to Devonian). Czech Geological Survey, Prague.

Chlupáč, I. 2003. Comments on facies development and stratigraphy of the Devonian, Barrandian area, Czech Republic. Bulletin of Geosciences 78(4), 299-312.

Chlupáč, I., Havlíček, V., KŘíž, J., Kukal, Z. \& Štorch, P.
1998. Palaeozoic of the Barrandian (Cambrian to Devonian). 183 pp. Czech Geological Survey, Prague.

Chlupáč, I., Hladil, J. \& LuKeš, P. 1986. Barrandian - Moravian Karst 1986. Excursion - Guidebook. Subcomission on Devonian Stratigraphy of the International Commission on Stratigraphy. 62 pp. Ústřední ústav geologický, Praha.

Chlupáč, I., Lukeš, P. \& ZikmundovÁ, J. 1979. The Lower/Middle Devonian boundary beds in the Barrandian area. Geologica et Palaentologica 13, 125-156.

Chlupéč, I. \& Turek, V. 1983. Devonian goniatites from the Barrandian area, Czechoslovakia. Rozpravy Ústředního ústavu geologického 46, 1-159.

Chlupáč, I. \& VANĚK, J. 1957. Nové nálezy fauny ve vyšších vrstvách koněpruského devonu. Časopis pro mineralogii a geologii 3, 349-351.

Cooper, G.A. 1956. Chazyan and related brachiopods. Smithsonian Miscellaneous Collection 127, 1-1245.

EMIG, C.C. 1982. Taxonomie du genre Lingula (Brachiopodes, Inarticulés). Bulletin du Muséum National d'Historie Naturelle de Paris (série 4) 4(3-4), 337-367.

EmIG, C.C. 1983. Taxonomie du genre Glottidia (Brachiopodes inarticules). Bulletin du Muséum National d'Historie Naturelle de Paris (série 4) 5(2), 469-489.

EMIG, C.C. 1997. Ecology of inarticulated brachiopods, 473-495. In Williams, A., Brunton, C.H.C., Carlson, S.J. et al. Treatise on Invertebrate Paleontology, part $\mathrm{H}$, Brachiopoda, Revised. Geological Society of America \& The University of Kansas, Boulder \& Lawrence.

Ferrová, L., Frýda, J. \& Lukeš, P. 2012. High-resolution tentaculite biostratigraphy and facies development across the Early Devonian Daleje Event in the Barrandian (Bohemia): implication for global Emsian stratigraphy. Bulletin of Geosciences 87(3), 587-624. DOI 10.3140/bull.geosci.1336

FRÝDA, J. 1992. Mode of life of a new onychochilid mollusc from the Lower Devonian of Bohemia. Journal of Paleontology 66(2), 200-205.

GRAY, J.E. 1840. Synopsis of the contents of the British Museum, $42^{\text {th }}$ edition. 370 pp. British Museum, London.

HavlíčEK, V. 1959. The Spiriferidae of the Silurian and Devonian of Bohemia (Brachiopoda). Rozpravy Ústředního ústavu geologického 25, 1-275.

HAVLíčEK, V. 1961. Rhynchonelloidea des böhmischen älteren Paläozoikums. Rozpravy Ústředního ústavu geologického 27, $1-211$.

HAVLÍČEK, V. 1971. Non-costate and weakly costate Spiriferidina (Brachiopoda) in the Silurian and Lower Devonian of Bohemia. Sborník geologických věd, Paleontologie 17, 7-34.

HavlíčEK, V. 1985. Karbous g. n. (Lissatrypidae, Brachiopoda; Devonian) in Bohemia. Věstník Ústředního ústavu geologického 60, 235-240.

HavlíčEK, V. 1987. Lower Devonian and Eifelian Atrypacea (Brachiopoda) in central Bohemia. Sborník geologických věd, Paleontologie 28, 61-115.

HavlíčEK, V. 1998. Review of brachiopods in the Chapel Coral Horizon (Zlíchov Formation, lower Emsian, Lower Devonian, Prague Basin). Věstník Českého geologického ústavu 73(2), $113-132$.

HavlíčEK, V. \& KuKal, Z. 1990. Sedimentology, benthic communities, and brachiopods in the Suchomasty (Dalejan) and 
Acanthopyge (Eifelian) Limestones of the Koněprusy area (Czechoslovakia). Sborník geologických věd, Paleontologie 31, 105-205.

HavlíčeK, V. \& Mergl, M. 1988. Two new discinid genera (Brachiopoda) from the Silurian and Devonian of the Prague Basin, Czechoslovakia. Věstník Českého geologického ústavu 63, 169-172.

HAVLÍ̌́EK, V. \& VANĚK, J. 1996. Brachiopods and trilobites in the Chýnice Limestone (Emsian) at Bubovice (Čeřinka hillside; Prague Basin). Palaeontologica Bohemiae 2, 1-16.

HAVlíčEK, V. \& VANĚK, J. 1998. Pragian brachiopods, trilobites, and principal biofacies in the Prague Basin (Lower Devonian, Bohemia). Sborník geologických věd, Paleontologie 34, 27-109.

HolmER, L.E. 1989. Middle Ordovician phosphatic inarticulate brachiopods from Västergötland and Dalarna, Sweden. Fossils and Strata 26, 1-172.

Holmer, L.E. \& Popov, L.E. 2000. Lingulata, 30-146. In WiLLiAms, A., Brunton, C.H.C. \& CARlson, S.J. et al. Treatise on Invertebrate Paleontology, part H, Brachiopoda, Revised, Volume 2. Geological Society of America \& University of Kansas, Boulder \& Lawrence.

KAто, M. 1996. The unique intertidal subterranean habitat and filtering system of a limpet-like brachiopod, Discinisca sparselineata. Canadian Journal of Zoology 74(11), 1983-1988. DOI 10.1139/z96-225

KING, W. 1846. Remarks on certain genera belonging to the class Palliobranchiata. Annals and Magazine of Natural History (series 1) 18, 26-42.

KLAPPER, G. 1977. Lower-Middle Devonian boundary conodont sequence in the Barrandian area of Czechoslovakia. Časopis pro mineralogii a geologii 22(4), 401-410.

Klapper, G., Ziegler, W. \& MashKova, T. 1978. Conodonts and correlation of Lower-Middle Devonian boundary beds in the Barrandian area of Czechoslovakia. Geologica et Paleontologica 12, 103-116.

Kunn, O. 1949. Lehrbuch der Paläozoologie. 326 pp. Schweizerbart, Stuttgart.

Kutorga, S.S. 1848. Ueber die Brachiopoden-familie der Siphonotretaceae. Russisch-Kaiserliche Mineralogische Gesellschaft zu St. Petersbourg, Verhandlungen 1847, 250-286.

LABARBERA, M. 1985. Mechanism of spatial competition of Discinisca strigata (Inarticulata, Brachiopoda) in the intertidal of Panama. Biology Bulletin 168, 101-105. DOI 10.2307/1541176

LENZ, A.C. 1993. A Silurian sponge-inarticulate brachiopod life? association. Journal of Paleontology 67(1), 138-139.

Lockley, M.G. \& ANTIA, D.D.J. 1980. Anomalous occurrences of the Lower Palaeozoic brachiopod Schizocrania. Palaeontology 23(3), 707-713.

Ludvigsen, R. 1974. A new Devonian acrotretid (Brachiopoda, Inarticulata) with unique protegular ultrastructure. Neues Jahrbuch für Geologie und Paläontologie, Monatshefte 3, 133-148.

Menke, C.T. 1828. Synopsis methodica molluscorum generum omnium et specierum earum quae in Museo Menkeano adservantur. 91 pp. G. Uslar, Pyrmonti.

Mergl, M. 1996. Discinid brachiopods from the Kopanina Formation (Silurian) of Amerika Quarries near Mořina, Bar- randian, Central Bohemia. Časopis Národního muzea, $\check{\text { Rada }}$ prírodovědná 165(1-4), 121-126.

Mergl, M. 1999. Genus Paterula (Brachiopoda) in OrdovicianSilurian sequence of Central Bohemia. Věstník Českého geologického ústavu 74(3), 347-361.

Mergl, M. 2001. Lingulate brachiopods of the Silurian and Devonian of the Barrandian. Acta Musei nationalis Pragae, Series $B$ - historia naturalis $57,1-49$.

Mergl, M. 2002. Linguliformean and craniiformean brachiopods of the Ordovician (Třenice to Dobrotivá Formations) of the Barrandian, Bohemia. Acta Musei nationalis Pragae, Series $B$ - historia naturalis 58(1-2), 1-82.

Mergl, M. 2006. A review of Silurian discinoid brachiopods from historical British localities. Bulletin of Geosciences 81(4), 215-236. DOI 10.3140/bull.geosci.2006.04.215

Mergl, M. 2008. Lingulate brachiopods from the Acanthopyge Limestone (Eifelian) of the Barrandian, Czech, Republic. Bulletin of Geosciences 83(3), 281-298.

DOI 10.3140/bull.geosci.2008.03.281

Mergl, M. 2010. A review of Silurian discinoid brachiopods from Gotland, Sweden. Bulletin of Geosciences 85(3), 367-384. DOI 10.3140/bull.geosci.1176

Mergl, M. \& FerrovÁ, L. 2009. Lingulate brachiopods from the Chýnice Limestone (upper Emsian, Barrandian; Czech Republic). Bulletin of Geosciences 84(3), 525-546. DOI 10.3140/bull.geosci.1143

Mergl, M. \& VodrÁŽKovÁ, S. 2012. Emsian-Eifelian lingulate brachiopods from the Daleje-Třebotov Formation (Třebotov and Suchomasty limestones) and the Choteč Formation (Choteč and Acanthopyge limestones from the Prague Basin; the Czech Republic. Bulletin of Geosciences 87(2), 315-332. DOI 10.3140/bull.geosci.1298

Newall, H. 1970. A symbiotic relationship between Lingula and the coral Heliolites in the Silurian, 335-344. In CRIMES, T. P. \& Harper, J. C. (eds) Trace Fossils. Seel House Press, Liverpool.

Prantl, F. \& PřIBYl, A. 1949. Studie o trilobitech nadčeledi Odontopleuracea nov. superfam. Rozpravy Státního geologického ústavu Československé republiky 12, 1-221.

Prantl, F. \& PřibYl, A. 1954. O českých zástupcích čeledi Harpedidae (Hawle et Corda). Rozpravy Státního geologického ústavu Československé republiky 18, 1-170.

Pвокор, R.J. 1987. The stratigraphical distribution of Devonian crinoids in the Barrandian area. Newsletter on Stratigraphy 17(2), 101-107.

Schuchert, C. 1893. Classification of the Brachiopoda. American Geologist 11, 141-167.

Schulze, R. 1968. Die Conodonten aus dem Paläozoicum der mittleren Karawanken (Seebergebiet). Neues Jahrbuch für Geologie und Paläontologie, Abhandlungen 130, 133-245.

ŠNAJDR, M. 1960. A study of the family Scutelluidae (Trilobitae). Rozpravy Ústředního ústavu geologického 26, 1-263.

ŠNAJDR, M. 1980. Bohemian Silurian and Devonian Proetidae (Trilobita). Rozpravy Ústředního ústavu geologického 45, $1-324$.

Sutton, M.D., Bassett, M.G. \& Cherns, L. 2000. Lingulate brachiopods from the lower Ordovician of the Anglo-Welsh Basin. Part. 2. Monograph of the Palaeontological Society 154(i, ii), 61-114. 
TAPANILA, L. \& Holmer, L.E. 2006. Endosymbiosis in Ordovician-Silurian corals and stromatoporoids: A new lingulid and its trace from Eastern Canada. Journal of Paleontology 88(4), 750-759. DOI 10.1666/0022-3360(2006)80[750:EIOCAS]2.0.CO;2

Telford, P.G. 1975. Lower and Middle Devonian conodonts from the Broken River Embayment, North Queensland, Australia. Special Papers in Palaeontology 15, 1-96.

VALEnTine, J.L. 2006. A thorny problem revisited: a cladistic analysis of the Siphonotretida (Linguliformea, Brachiopoda), 261-342. In VAlEntine, J.L. Taxonomic assessment, biostratigraphy and faunal turnover of Silurian-early Devonian linguliformean brachiopods from New South Wales, Australia. MS, Ph.D. thesis, Macquarie University, Sydney.

Valentine, J.L., Brock, G.A. \& Molloy, P.D. 2003. Linguliformean brachiopod faunal turnover across the Ireviken Event (Silurian) at Boree Creek, central-western Now South Wales, Australia, 301-327. In Königshof, P. \& Schindler, E. (eds) Mid-Palaeozoic bio- and geodynamics: the north GondwanaLaurasian interaction. Courier Forschundsinstitut Senckenberg 242.

VAŠKANINOVÁ, V. \& KRAFT, P. 2014. The largest Lower Devonian placoderm - Antineosteus rufus sp. nov. from the Barrandian area (Czech Republic). Bulletin of Geosciences 89(3), 635-644. DOI 10.3140/bull.geosci.1450

Waagen, W. 1885. Salt Range fossils, I. Productus-Limestone fossils, Brachiopoda. Memoirs of the Geological Survey of India, Palaeontologica Indica (series 13) 4(5), 729-770.

Weddige, K. 1977. Die Conodonten der Eifel-Stufe im Typusgebiet und in benachbarten Faciesgebieten. Senckenbergiana lethaea 58(4/5), 271-419.

Willard, B. 1928. The brachiopods of the Ottosee and Holston formations of Tennessee and Virginia. Bulletin of the Harvard Museum of Comparative Zoology 68, 255-292.

Wright, A.D. \& NõLVAK, J. 1997. Functional significance of the spines of the Ordovician lingulate brachiopod Acanthambonia. Palaeontology 40(1), 113-119.

Zhang, Z.F., Han, J., Zhang, X.L., Liu, J.N. \& Shu, D.G. 2004. Soft tissue preservation in the Lower Cambrian linguloid brachiopod from South China. Acta Palaeontologica Polonica 49, 259-266.

Zhang, Z.F., Shu, D.G., Han, J. \& LiU, J.N. 2007. A gregarious lingulid brachiopod Longtancunella chengjiangensis from the Lower Cambrian, South China. Lethaia 40, 11-18. DOI 10.1111/j.1502-3931.2006.00002.x

ZIEGLER, W. 1956. Unterdevonische Conodonten, insbesondere aus dem Schönauer und dem Zorgenis-Kalk. Notizblatt des Hessischen Landesamtes für Bodenforschung 84, 93-106. 